\title{
Federated States of Micronesia: 2010 Article IV Consultation-Staff Report; a Public Information Notice; and a Statement by the Executive Director of the Federated States of Micronesia on the Executive Board Discussion.
}

Under Article IV of the IMF's Articles of Agreement, the IMF holds bilateral discussions with members, usually every year. In the context of the 2010 Article IV consultation with the Federated States of Micronesia, the following documents have been released and are included in this package:

- $\quad$ The staff report for the 2010 Article IV consultation, prepared by a staff team of the IMF, following discussions that ended on November 17, 2010, with the officials of the Federated States of Micronesia on economic developments and policies. Based on information available at the time of these discussions, the staff report was completed on December 22, 2010. The views expressed in the staff report are those of the staff team and do not necessarily reflect the views of the Executive Board of the IMF.

- $\quad$ A Public Information Notice (PIN) summarizing the views of the Executive Board as expressed during its January 26, 2011 discussion of the staff report that concluded the Article IV consultation.

- A statement by the Executive Director for the Federated States of Micronesia.

The policy of publication of staff reports and other documents allows for the deletion of market-sensitive information.

Copies of this report are available to the public from

International Monetary Fund • Publication Services

$70019^{\text {th }}$ Street, N.W. • Washington, D.C. 20431

Telephone: (202) 623-7430 • Telefax: (202) 623-7201

E-mail: publications@imf.org • Internet: http://www.imf.org

\section{International Monetary Fund Washington, D.C.}




\title{
INTERNATIONAL MONETARY FUND
}

\author{
FEDERATED STATES OF MICRONESIA
}

\section{Staff Report for the 2010 Article IV Consultation}

\author{
Prepared by the Staff Representatives for the 2010 Consultation with the \\ Federated States of Micronesia \\ Approved by Kenneth Kang and James Roaf
}

December 22, 2010

- Discussions. The mission took place during November 8-17, 2010 in Pohnpei and Chuuk and met with the President, the Secretary of Finance, the Vice-Speaker of Congress, and other senior members of national and state governments, as well as parliamentarians, private sector representatives, and foreign donors.

- Team. Mr. Yoshida (head), Ms. Berkmen and Mr. Lam (all APD). Mr. Pereira (OED) and Ms. Pedersen (AsDB) participated in the discussions.

- Outreach. The mission held meetings with business leaders and the legislature of Chuuk and of Pohnpei.

- Past Fund advice. During the 2008 Article IV consultation, the authorities and the Fund agreed on the broad policy priorities - fiscal adjustment through expenditure cuts and tax reforms to achieve self-sufficiency when the Compact grants end in 2023 and structural reforms to support private sector development. The authorities have made progress in improving fiscal balance and drafting tax reform bills, but implementation has been slow, partly due to coordination problems among the various states.

- Mission focus: Discussions focused on policies to secure a sustained recovery and long-term economic and fiscal sustainability.

- Exchange rate. The Federated States of Micronesia (FSM) has accepted the obligations of Article VIII, Sections 2, 3, and 4. The exchange system is free of restrictions on the making of payments and transfers for current international transactions. The U.S. dollar is the legal tender.

- Technical assistance. Pacific Financial Technical Assistance Centre (PFTAC) has provided assistance in bank supervision and drafting of the tax law.

- Statistical issues. Limited domestic capacity to produce economic data hampers surveillance and policy analysis. 


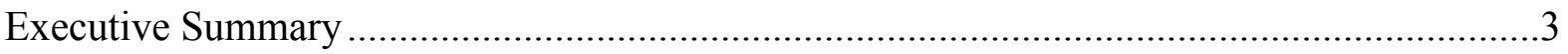

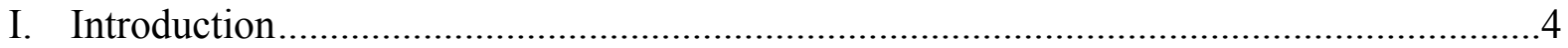

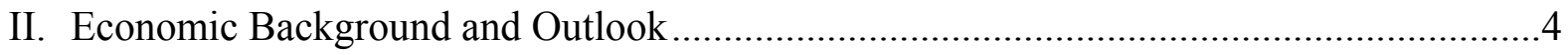

III. Policies to Achieve Sustainable Growth ..................................................................

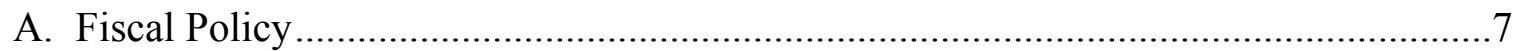

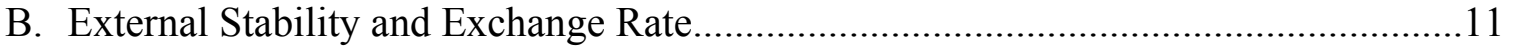

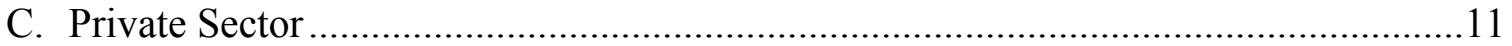

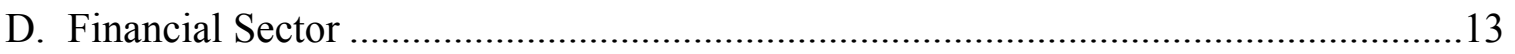

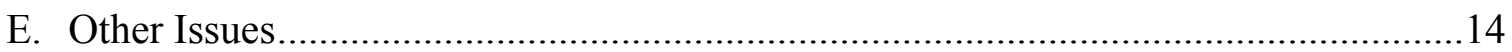

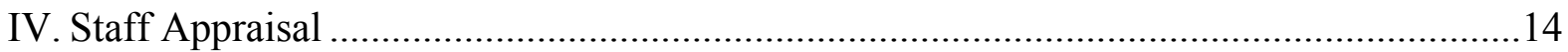

Boxes

1. Public Finance in the State of Chuuk.......................................................................6

2. Challenges for Northern Pacific Islands Countries with Compact Grants .......................8

Figures

1. Regional Comparison of Recent Developments ...................................................... 16

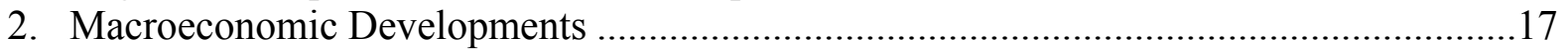

3. Developments in the Exchange Rate, Export Growth,

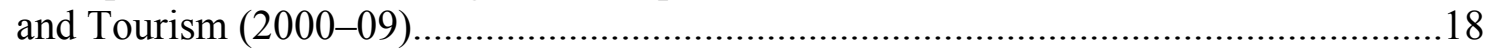

Tables

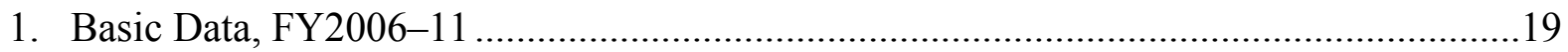

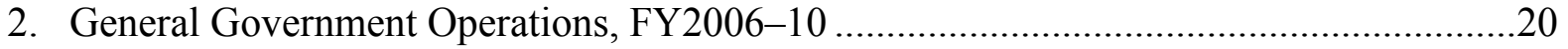

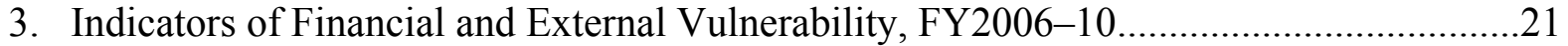

4. Balance of Payments, FY2006-10 ............................................................................22

5. Medium-term Scenario (Current Policies), FY2007-15 .............................................23

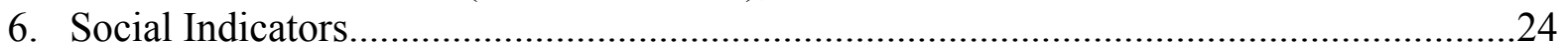

Appendix

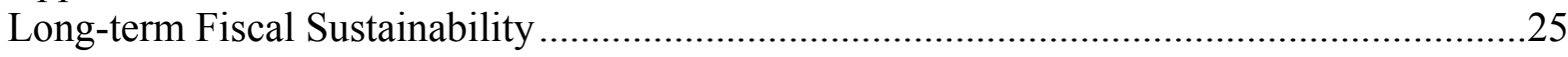




\section{EXECUTIVE SUMMARY}

Economic environment. The economy has recovered following the stabilization of commodity and food prices. The recovery, however, is mainly supported by public infrastructure projects, and private sector activity remains weak. The fiscal situation has somewhat improved, but spending pressures are building up with elections approaching.

Outlook and risks. While the gradual release of delayed infrastructure grants is expected to stimulate the economy, structural impediments to private sector development and volatile commodity prices could hold back the recovery. Given the lack of private sector initiatives, the planned decrements in Compact grants and continued outward migration, medium-term growth will likely remain weak.

Fiscal sustainability. Achieving long-term budgetary self-reliance has become more challenging after the global crisis. Lower than anticipated returns on the government's trust fund imply a large projected revenue shortfall in FY2023, when the annual Compact grants are set to expire. Closing this revenue gap would require a medium-term fiscal surplus of about $53 / 4$ percent of GDP.

Fiscal reforms. The tax reform bills have been submitted to the national congress; the technical issues regarding the constitutionality of the bills appear to have been resolved, and support for the tax reform at State level seems strong. Further strengthening of tax administration efforts, personnel training, and public education in parallel with the legislative process carry utmost importance.

Private sector development. Weak private sector development continues to hold back sustainable economic growth. With a number of infrastructure projects completed, reforms to attract foreign direct investment (FDI) could generate significant benefits. The policy priorities would be to relax the restrictive FDI legislation, increase the supply of skilled labor, and accelerate the implementation of pending infrastructure projects.

Financial sector. The banking sector remains liquid, but contributes little to economic growth. Activities by the public development bank and credit unions are currently not regulated and should be brought under the supervision of the Banking Board. Insurance supervision has recently been separated from banking supervision, but its supervisory capacity is inadequate and should be immediately stepped up, particularly in the area of captive insurance. 


\section{INTRODUCTION}

1. The Federated States of Micronesia (FSM) is a small Pacific Island country highly dependent on external aid, mainly from the United States. ${ }^{1}$ A renewed Compact of Free Association Agreement ("Compact") with the United States effective since FY2004 2 steadily lowers transfers to the FSM through FY2023. Thereafter, the FSM is expected to complement its domestic revenues with returns from its Compact Trust Fund (CTF) and other savings. The amended Compact has tightened rules on reporting, auditing, and the use of grants, which have proved difficult for the national and state governments to meet. As a result, about $\$ 150$ million (over 50 percent of GDP) in grants has not been used, contributing to weak economic performance in recent years.

2. The Article IV discussions focused on policies to secure a sustained recovery and achieve long-term economic and fiscal sustainability. In addition to delays in Compact disbursements, the surge in global commodity prices and the global financial crisis have taken a heavy toll on the FSM economy. The economy has contracted since FY2006, and the value of the CTF has declined significantly. The political environment for reforms remain challenging with presidential elections scheduled for March 2011, which could delay the passage of key tax legislation. Against this background, the discussions focused on the fiscal and structural policies needed to secure a recovery and achieve long-term sustainability.

\section{ECONOMIC BACKGROUND AND OUTLOOK}

3. Since the last Article IV consultation, the economy has improved. Following a long period of contraction, the economy grew for the first time in three years by 0.4 percent in FY2009, supported mainly by the airport renovation and other infrastructure projects, the reopening of a freezing plant in Kosrae, and the rise in subsistence agriculture. The shift to subsistence farming reflects the rise in commodity prices and the loss of employment in public sector in certain

\begin{tabular}{|c|c|c|c|c|}
\hline \multicolumn{5}{|c|}{ Selected Economic Indicators } \\
\hline & $\begin{array}{c}\text { Average } \\
\text { FY2004-2008 }\end{array}$ & FY2009 & $\begin{array}{l}\text { Est. 1/ } \\
\text { FY2010 }\end{array}$ & $\begin{array}{l}\text { Proj. } \\
\text { FY2011 }\end{array}$ \\
\hline & \multicolumn{4}{|c|}{ (year-on-year changes) } \\
\hline Real GDP & -1.3 & 0.4 & 0.4 & 0.5 \\
\hline \multirow[t]{2}{*}{ Consumer price index } & 4.1 & 7.7 & 3.5 & 2.0 \\
\hline & \multicolumn{4}{|c|}{ (in percent of GDP) } \\
\hline Consolidated fiscal balance & -5.9 & 1.6 & 0.4 & 0.1 \\
\hline Current account balance & -12.2 & -18.6 & -18.4 & -17.0 \\
\hline
\end{tabular}
states. Inflation is estimated to have significantly slowed to 3.5 percent $(y / y)$ in FY2010, after reaching 7.7 percent in FY2009, due to moderating food prices and decline in fuel and services prices.

\footnotetext{
${ }^{1}$ The FSM (with a population of about 102,000) has four states - Chuuk, Kosrae, Pohnpei, and Yap, each with its own executive and legislative bodies. Authority is highly decentralized, with state governments significantly larger than the national authority.

2 The fiscal year runs from October to September (for example, FY2010 covers October 2009 to September 2010).
} 
4. The consolidated fiscal balance has also improved, but with differences across states. Chuuk and Kosrae have reduced public employment and salaries in line with the annual decline in Compact grants. Fishing fees temporarily increased along with the rise in fish catch, while tax revenues have expanded thanks to improved tax administration. As a result, the consolidated overall balance recorded its first surplus in six years of 1.6 percent of GDP in FY2009. However, performance varied across states, with Chuuk achieving a modest surplus and Yap and Pohnpei continuing to draw down their savings. In Chuuk, which is still struggling over a significant amount of debt (See Box 1), the authorities highlighted the difficulties in containing expenditures, given the already reduced working hours for non-Compact public employees, but nevertheless remained committed to keeping a balanced budget.

5. The current account deficit widened and external debt rose in FY2009. High fuel prices and grant-financed imports related to construction activities have worsened the current account. At the same time, external debt rose significantly in FY2009 mainly due to the \$12 million borrowing by the FSM Telecom to finance fiber-optic installation, but the level of debt has remained relatively low at about 30 percent of GDP and is mostly on concessional terms.

6. The recovery will likely remain weak, and the consolidated fiscal surplus is expected to decline in the near term. Growth in FY2010 is estimated at 0.4 percent, supported mainly by infrastructure projects. The near-term outlook is overshadowed by sluggish private sector growth, which has been unable to offset the scheduled annual decline in Compact grants. Medium-term growth is estimated to increase slightly to 0.6 percent, supported by additional infrastructure projects in the pipeline. The fiscal surplus is expected to decline through FY2010-11 with the gains in tax revenues more than offset by the decline in fishing fees and increase in current expenditures related to the upcoming elections. The current account is expected to remain in deficit due to imports from ongoing infrastructure projects.

7. Risks are on the downside. While the release of delayed infrastructure funds is expected to stimulate the economy, structural impediments to private sector development and volatile commodity prices could hold back the recovery, leading to further delays in fiscal adjustment, and elevating sustainability concerns. Long-term risks include the possible loss of fish stock and reduction of farmland due to climate change and growing outward migration.

\section{The authorities acknowledged the challenges facing the FSM in offsetting}

Compact decrements. In this context, they are currently in the process of developing statespecific solutions through a nationwide economic symposium to look into ways of promoting private sector and reducing import dependence by shifting to local production. To better manage risks stemming from volatile commodity prices, they are also considering developing an energy policy in line with best practices in other resource scarce countries. 


\section{Box 1. Micronesia: Public Finance in the State of Chuuk}

Although Chuuk State has gone through significant fiscal adjustment since FY2007, it still faces major challenges in reducing its sizeable debt. Based on the report prepared for the Compact, the debt liabilities stood at about \$28.9 million (about 37 percent of state GDP) as of FY2009, including loans to Asian Development Bank (AsDB) and accumulated arrears for land acquisition and vendor payments. To reduce arrears and expenditure related to the non-conforming uses of the capacity-building sector grant, the state undertook a decisive fiscal consolidation in FY2008-09 through a severe public workforce downsizing of about 300 people (about 13 percent of state public employment) and by reducing working hours for non-Compact related employees from 80 hours to 64 hours. As a result, fiscal balance has been restored since FY2008.

The authorities are expected to maintain fiscal discipline in FY2010 and FY2011. A small fiscal surplus is expected for FY2010, partly reflecting higher tax collections due to improved tax administration. While the authorities intend to remain current with the expenditures, they still fall short of making contributions to the infrastructure maintenance fund. For FY2011, the authorities envisage a balanced budget.

A debt relief task force has been established to explore ways of reducing the debt. The accumulated debt is sizeable and its reduction will be a major challenge. Proposed measures to reduce debt include selling of the state holdings of bank shares, earmarking a one percent increase in the sales tax for debt servicing, and canceling the cross-claims with the utility company, but they are not likely to be enough to reduce the debt significantly. The authorities are, therefore, looking into other options to rollover the debt, including through bond issuance or borrowing from commercial banks. However, staff strongly cautioned against refinancing existing debt with new debt, pointing to the possibility of significant increase in future debt burden unless adequate fiscal surpluses are secured.

Staff encouraged the authorities to continue building up fiscal surpluses to reduce accumulated debt rather than simply earmarking tax revenues. In this context, the authorities and staff agreed on the importance of verifying amounts owed in accordance with the existing laws and accumulating fiscal surpluses by resisting the pressures to increase wage bill and limiting the non-Compact funded expenditures. Staff cautioned in particular against plans to prematurely increase the working hours of non-Compact financed public employees.

Improving the governance and implementation of Compact grants can further enhance their effectiveness. The problems regarding land title issues, lack of qualified personnel, and weak project planning have caused significant delays in the implementation of infrastructure projects. While performance audits for Compact sectoral projects are conducted, the enforcement of the findings has been weak. For example, the public auditor's office identified problems regarding procurement practices, but there is no effective implementation process in action. The effectiveness of the grants can be enhanced by introducing mechanisms ensuring the enforcement of the improvements identified by the auditors, detailed project planning at an early stage, and contracting of qualified personnel at both manager and technical level. In this context, the efforts by legislature to resolve the land title issues and the ongoing effort of better contracting practices are an encouraging sign. 


\section{Policies to AChieve Sustainable Growth}

\section{A. Fiscal Policy}

9. Achieving long-term fiscal sustainability has become more challenging. Staff projections indicate that the resources in $\mathrm{CTF}$ and other unreserved accounts will not be able to supplement expiring Compact-related grants in FY2023 without significantly disrupting public services (Appendix I). Owing to the sharp drop in global equity markets, CTF experienced a cumulative net investment loss of around 17 percent over FY2008-FY2009, before recovering partly in FY2010. Based on conservative investment returns, limited fiscal adjustments, and structural reforms, the income shortfall is projected to reach $\$ 16$ million (about 6 percent of FY2010 GDP) when Compact sector grants expire in FY2023, higher than the estimates ( 5 percent of GDP) in the 2008 Article IV Consultation report. The authorities agreed that even if the returns on assets recover, the CTF will likely not generate enough revenue to maintain the same level of government operations in FY2024.

\section{Long-term sustainability could be achieved through increasing the fiscal surplus}

\section{to around 5 $3 / 4$ percent of GDP by}

FY2015. This would involve raising the fiscal surplus by about 1.1 percentage point per year (equivalent to $\$ 3.7$ million in 2010 prices) for five years, and then maintaining the surplus at that level until FY2023. Under the FSM's federal system, each state would need to run surpluses to supplement the CTF returns. Staff encouraged the

\begin{tabular}{|c|c|c|c|c|c|}
\hline & \multicolumn{3}{|c|}{ Fiscal balance } & \multirow{2}{*}{\multicolumn{2}{|c|}{$\begin{array}{c}\text { Fiscal surpluses (in } \\
\text { FY2010 prices) } \\
\text { FY2015 } \\
\text { Proj. }\end{array}$}} \\
\hline & \multirow{2}{*}{$\begin{array}{l}\text { FY2009 } \\
\text { in USD } \\
\text { millions }\end{array}$} & \multicolumn{2}{|c|}{$\begin{array}{c}\text { FY2010 } \\
\text { Est. }\end{array}$} & & \\
\hline & & $\begin{array}{l}\text { in USD } \\
\text { millions }\end{array}$ & $\begin{array}{l}\text { in percent } \\
\text { of GDP }\end{array}$ & $\begin{array}{l}\text { in USD } \\
\text { millions }\end{array}$ & $\begin{array}{l}\text { in percent } \\
\text { of GDP }\end{array}$ \\
\hline National government & 5.4 & 2.0 & 0.7 & 2.7 & 0.9 \\
\hline Chuuk & 2.5 & 0.4 & 0.1 & 4.3 & 1.4 \\
\hline Kosrae & 0.4 & 0.1 & 0.0 & 1.0 & 0.3 \\
\hline Pohnpei & -1.3 & -0.3 & -0.1 & 6.7 & 2.2 \\
\hline Yap & -2.4 & -1.2 & -0.4 & 2.7 & 0.9 \\
\hline FSM (consolidated basis) & 4.6 & 1.0 & 0.4 & 17.4 & 5.8 \\
\hline Memorandum item: & & & & & \\
\hline Nominal GDP & 276.5 & 287.4 & & 303.3 & \\
\hline
\end{tabular}
authorities to start the adjustment in FY2011, as further delay would increase the cost of adjustment (See appendix I). While the authorities recognized the need for the early adjustment, they noted the difficulties in starting next fiscal year due to spending pressures related to Presidential elections and challenges in coordinating fiscal policies across the states.

11. In the near term, containing current expenditures will remain essential. While there has been considerable progress in reducing public employment in Chuuk and Kosrae, wages and salaries of the national government increased significantly in FY2009. Other Compact economies face similar challenges in adjusting, but there is room for FSM to curtail current expenditures which remain high when compared to other Pacific Island economies. Also, public wages remain much higher than in the private sector and have grown rapidly compared to other Compact economies (See the table and Box 2). Authorities and staff agreed on the

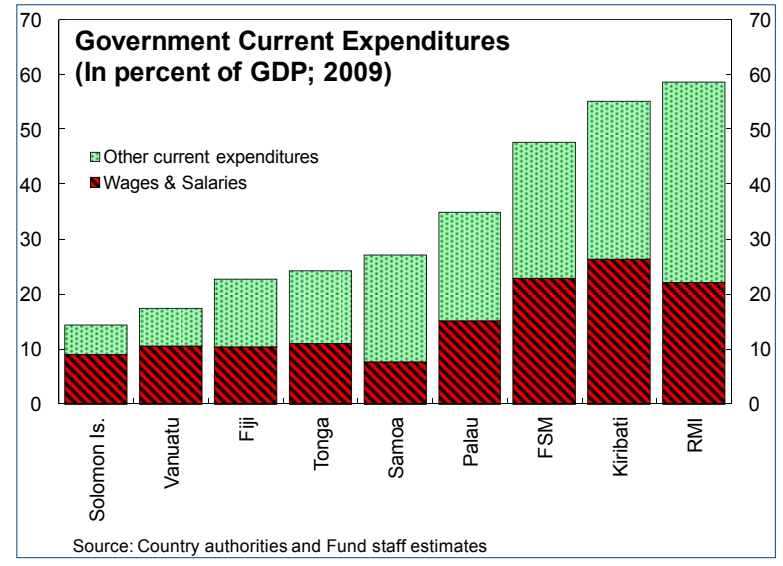


need to curtail expenditures, in particular public wages, but underscored the challenges ahead. In Pohnpei, the mission supported the planned expenditure cuts, but recommended a more targeted approach rather than across the board reductions.

\section{Box 2. Micronesia: Challenges for Northern Pacific Islands Countries with Compact Grants}

Many northern Pacific Island countries (PICs), including FSM, Marshall Islands (RMI), and Palau, are likely to face significant fiscal adjustment and reform challenges under the Compact. These countries are highly dependent on foreign grants, with a sizeable public sector. Despite a large share of foreign grants devoted to capacity building and private sector development, implementation has been slow and large gaps persist in attaining budgetary self-sufficiency. This box discusses the challenges for these three countries in overcoming their heavy reliance on Compact grants.

Most foreign grants in these three countries are through the financial provisions under the Compact agreement with the United States. For the FSM and RMI, sector grants from the amended Compact are set to expire in FY2023, while Palau's new agreement with the United States lasts for 15 years until FY2024. Grants under the agreement are about $\$ 250$ million. In recent years, foreign grants accounted for about 50-60 percent of the overall revenue in these countries, with Compact-related grants making up a large portion.

Heavy dependence on grants translates into large fiscal imbalances and sizeable public sectors. While overall fiscal positions are roughly in balance across all three countries, their current deficits excluding grants are significant between 15 percent and 35 percent of GDP (Figure B2.1). With domestic revenues about at the same level as public wages across all three countries, these countries rely entirely on foreign grants to finance other current expenditures and capital spending. The overall public sector (including public enterprises) accounts for more than half of the economy, crowding out private sector activity. Public sector payrolls far exceeded those in the private sector in the FSM and RMI and wage gaps have remained since the amended Compact agreements took effect in FY2004. In the FSM, the public sector wages increased substantially in FY2009, particularly for the national government.

In light of their heavy reliance on grants, significant fiscal adjustment is needed in all three countries to ensure fiscal sustainability. The required size of adjustment in staff estimates varies across the three countries, reflecting factors such as different arrangements under the Compact, and ranges from about 5 percent of GDP for RMI, around 53/4 percent of GDP for FSM, to about 8 percent of GDP for Palau. However, in all three, the required medium-term adjustment is substantial, requiring a comprehensive approach combining expenditure cuts, revenue improvements, and structural reforms (Table B2.1). A delay in adjustment would result in more costly and difficult adjustments in the future. 


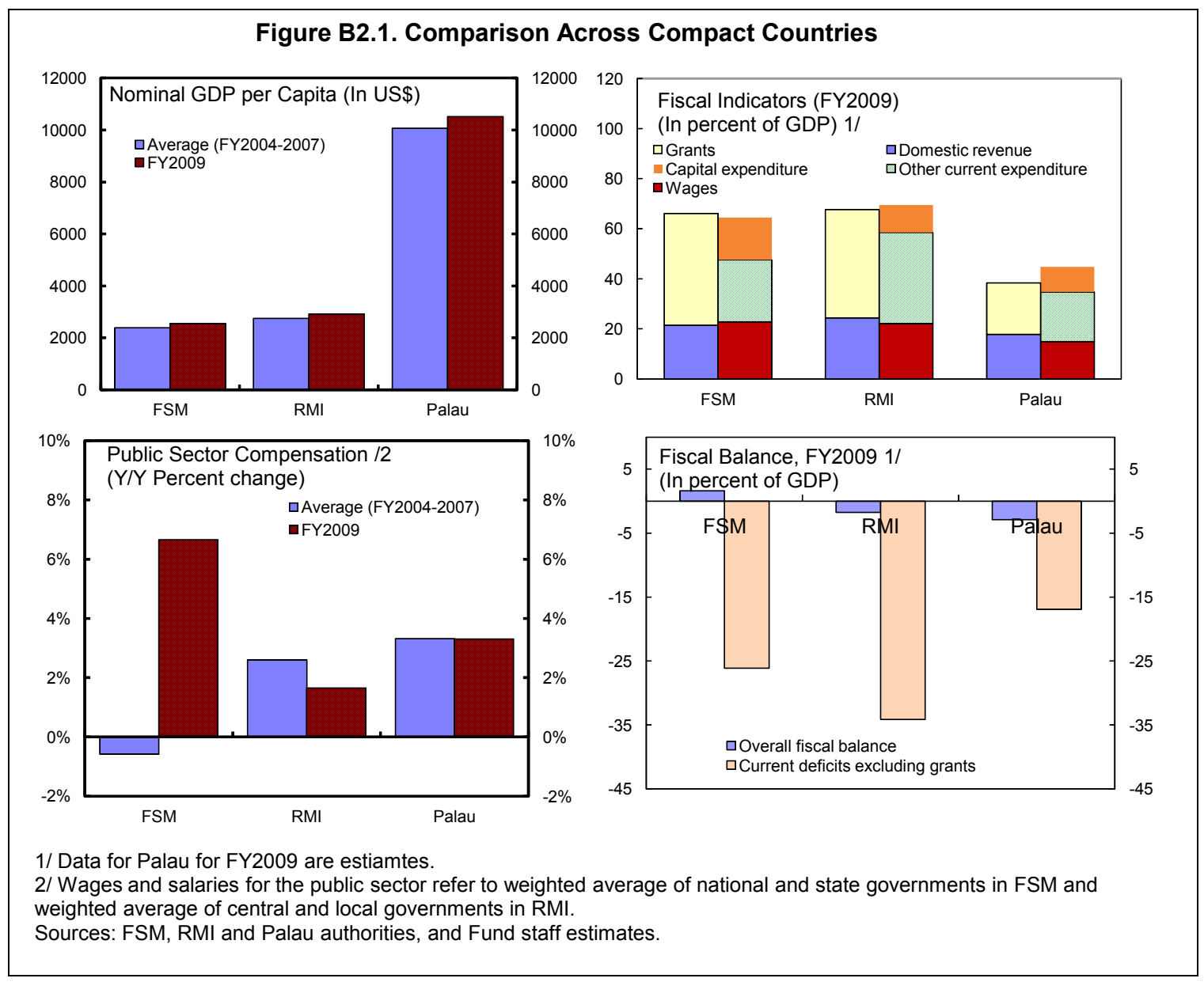

Table B2.1. Summary of Recommended Measures to Achieve Long-term Fiscal Sustainability

\begin{tabular}{|c|c|c|c|}
\hline & FSM & RMI & Palau \\
\hline Revenue measures & $\begin{array}{l}\text { National congress and state } \\
\text { legislators need to expedite the } \\
\text { approval of the tax reforms. }\end{array}$ & $\begin{array}{l}\text { Expedite tax reform process } \\
\text { by drafting the legislature and } \\
\text { public outreach. } \\
\text { Strengthening tax } \\
\text { administration through audit for } \\
\text { unreported income. }\end{array}$ & $\begin{array}{l}\text { - Improve tax system by } \\
\text { eliminating import duty } \\
\text { exemptions and replacing the } \\
\text { GRT with less distortionary tax. }\end{array}$ \\
\hline Expenditure measures & $\begin{array}{l}\text { - Contain civil service payrolls and } \\
\text { public sector employment. } \\
\text { - Adopt a multi-year fiscal plan to } \\
\text { ensure fiscal prudence and guard } \\
\text { against election-related spending. }\end{array}$ & $\begin{array}{l}\text { Reudce civil service payrolls } \\
\text { - Limit financial support to state- } \\
\text { owned enterprises (SOEs). }\end{array}$ & $\begin{array}{l}\text { Further reduce public sector } \\
\text { wage expenditure } \\
\text { Curtail subsidies on water and } \\
\text { sewage services }\end{array}$ \\
\hline Other structural measures & $\begin{array}{l}\text { Undertake reforms to encourage } \\
\text { FDI; harmonize FDI legislature } \\
\text { across states. }\end{array}$ & $\begin{array}{l}\text { Undertake comprehensive } \\
\text { reforms to SOEs (e.g., } \\
\text { establish an SOE policy with } \\
\text { ADB assistance). }\end{array}$ & $\begin{array}{l}\text { Strengthen budget processes } \\
\text { by improving cash management; } \\
\text { liberalize the FDI regime; improve } \\
\text { land regulation. }\end{array}$ \\
\hline
\end{tabular}

Sources: Various IMF Article IV Consultation Reports. 
12. In this context, a multi-year fiscal plan would strengthen the fiscal discipline.

Over the medium term, net current expenditure cuts of about $23 / 4$ percent of GDP would be needed in addition to revenue gains from the tax reform (Appendix I). ${ }^{3}$ To achieve this, the FSM should adopt a medium-term fiscal consolidation plan with clear

\begin{tabular}{|c|c|c|c|c|}
\hline \multicolumn{5}{|c|}{ Micronesia: Average Nominal Wages by Sector } \\
\hline & Government 1/ & SOES & $\begin{array}{l}\text { Private } \\
\text { sector }\end{array}$ & $\begin{array}{c}\text { Government / private } \\
\text { sector wage }\end{array}$ \\
\hline & \multicolumn{4}{|c|}{ Wage level, USD (FY2009) } \\
\hline Chuuk & 7,957 & 8,406 & 3,445 & 2.3 \\
\hline Kosrae & 8,944 & 10,709 & 3,739 & 2.4 \\
\hline Pohnpei & 13,088 & 14,787 & 4,721 & 2.8 \\
\hline Yap & 7,637 & 7,086 & 4,564 & 1.7 \\
\hline FSM: weighted average & & & & \\
\hline across states & 9,744 & 12,475 & 4,309 & 2.3 \\
\hline
\end{tabular}
targets for public wages and other administrative spending. A multi-year plan would also guard against election-related spending and secure the gains from painful expenditure cuts over the past few years, while safeguarding critical spending on health care, education and infrastructure. For such a plan to be credible, effective public communication is essential.

\section{Building the right incentive mechanism into the public financial management is}

key. In this context, similar to those on Compact-funded expenditures, public performance audits should be extended to cover general operations financed by local revenues. The authorities should ensure that subsequent enforcement of the audit findings, such as weak procurement practices, is followed through and incorporated into budget planning.

\section{Even with significant expenditure cuts, swift implementation of the planned tax} reform is still needed. Despite the wide recognition of the importance of a comprehensive tax reform, progress has stalled. A set of tax reform bills to create a Unified Revenue Authority (URA), and introduce net profits tax and value added tax (VAT), in place of the current gross revenue tax and sales tax, has been submitted to Congress. These reforms should generate additional revenue amounting about 3 percent of GDP. Although the technical problems regarding the constitutionality of the URA and the VAT appear to be resolved, prospects for completion of tax reform are still uncertain with political priorities shifting towards the upcoming election and continued coordination problems among the national and state governments. National and state legislatures are not likely to pass the bills before the March 2011 elections, with each legislature waiting for the other to move first. The Congressional leaders are planning to visit states in attempts to break the gridlock.

15. Although tax administration has improved, there is still room to enhance current operations of the state and national tax offices and expand personnel training. This, if done in parallel with the legislative process of tax reform bills, would help facilitate a smooth transition to the new system and avoid a fall in the tax collection. In addition, expanding communication and the consultation process to involve community groups, including small enterprises, would help generate more broad-based support for the legislative process. The

\footnotetext{
${ }^{3}$ The expenditure adjustment is on net terms after accounting for scheduled decrements of Compact grants.
} 
authorities agreed with the proposed approach and noted the need for technical assistance on personnel training during the process.

\section{The mission supported the steps to reduce unfunded liabilities of the social} security system. As highlighted by the authorities, unfunded liabilities of the social security are large at about \$232 million (89 percent of GDP) as of January 2009 . To address the problem, the authorities passed a new bill in 2010, increasing social security tax rates by 2 percentage points and reducing benefits by 50 percent for retirement before the age of 65. Staff supports the move and encourages the authorities to monitor closely the projected balance of social security funds for any deviation from the targeted path given that these measures provide only a partial relief going forward.

\section{B. External Stability and Exchange Rate}

\section{The FSM has experienced a real appreciation since the global downturn.}

Following the surge of domestic food and fuel prices in FY2008, the real effective exchange rate has appreciated by 9 percent, posing a risk of loss of competitiveness with respect to other Pacific Islands countries. Looking forward, the FSM could regain competitiveness as the pressure to domestic prices subsides or reforms to improve productivity take hold. The authorities acknowledged such risks but noted that their main export items, particularly niche tourism, are not sensitive to the exchange rate or changes in global demand.

18. Despite the appreciation, the risks to external stability are limited, and the use of the U.S. dollar as currency remains appropriate given the size and the links of the economy. While tourist arrivals and overall exports fell more than those of regional peers, staff and authorities agreed that the Compact grants would continue to provide a stable source of funding over the next decade and the U.S. dollar remain the appropriate currency.

19. However, increased debt repayment on foreign loans (about $1 \frac{1}{2}$ percent of GDP) and scheduled decrements of Compact grants could create some pressure and would require careful monitoring of the external position. The authorities are considering a foreign denominated loan from the Export-Import Bank of China amounting \$20-25 million (about 7-9 percent of GDP) to upgrade a Pohnpei fishing processing plant. While the details of the loan and its commercial viability are not yet decided, staff recommended a careful consideration of the terms of the loan, including its currency risk, debt repayment burden, and potential government obligation involved, in view of its possible impact on external debt sustainability.

\section{Private Sector}

20. The private sector in the FSM is stagnant and contributes little to growth. The authorities highlighted several obstacles for vibrant private sector development including difficulties in land tenure and registration, poor infrastructure, lack of skilled labor, a large public and private sector wage differential, limited access to credit by start-ups, and 
regulatory hurdles for inward FDI. ${ }^{4}$ They also emphasized difficulties stemming from high transportation costs and energy prices.

21. The FSM has recently completed a number of key infrastructure projects, which could support the private sector. The extension of Pohnpei airport, to be completed in mid2011, has the potential for expanding tourism with direct flights from the region and more broadly Asia. It also has the potential for increasing niche exports, such as fish, sakow (local alcohol drink), and other agricultural products. The authorities noted that the relocation of a U.S. Marine base to Guam is also likely to expand opportunities for both tourism and agriculture. The expanded fiber-optic network, completed in 2010, is expected to improve overseas communication.

\section{Building on these infrastructure projects, reforms to attract inward FDI could} generate significant gains. Greater FDI is especially feasible in the areas of aquaculture, agriculture, and tourism. In order to seize this opportunity the FSM needs to overcome many challenges:

- $\quad$ FDI Legislation. The Foreign Investment Act in several states are restrictive, with regards to both ownership and renting of the land, and investment approval. The Acts should be reviewed to ensure an environment conducive to FDI, while respecting local investors' legitimate interests. Harmonizing FDI legislation across states could also reduce investment uncertainty and facilitate large-scale FDI. Greater clarity on land tenure and regulation, which varies by states, would also help. In this context, staff welcomes the proposal to relax the Pohnpei Foreign Investment Act along these lines.

- $\quad$ Lack of skilled labor. The limited availability of skilled labor holds back FDI. Improving education and vocational training while relaxing legal restrictions on hiring of expatriates may help ease this barrier. At the same time, joint ventures would create positive spillover effects through skill transfers.

- Inadequate infrastructure. Without reliable infrastructure in power, transportation, and communications, foreign investors face steep challenges in entering the FSM. With about US\$150 million still not utilized, greater utilization of Compact infrastructure grants should be given priority. In this context, improving project management and procurement of resources would accelerate the existing projects in the pipeline.

23. The authorities shared the staff's view that the FSM business environment remains very challenging. On FDI, the Pohnpei legislators noted that the Foreign Investment Act of the state was very restrictive and were considering revision to make it more investment friendly. The Pohnpei government also acknowledged the slow progress in

\footnotetext{
${ }^{4}$ In the most recent Doing Business report by the World Bank, the FSM ranks $141^{\text {st }}$ out of 183 countries in the world, the lowest among Pacific Island countries in terms of the ease of doing business. The FSM fares especially poorly in such areas as registering properties (183th) and protecting investors (173th).
} 
mapping, surveying, and certification of land and the need to step up efforts in these areas, in view of their critical role in supporting private activities. Some private sector representatives, on the other hand, expressed reservations regarding foreign investment, pointing to potential negative impacts stemming from limited use of domestic factors of production and knowledge spillover.

\section{Financial Sector}

\section{The banking system remains liquid, but renders little support to the private} sector. Since the last Article IV, non-performing loans have declined to about $23 / 4$ percent of total loans, and banks have maintained sufficient liquidity with a loan to deposit ratio of about 36 percent in FY2010. The risk-adjusted capital ratio stays high at over 30 percent. The increase in deposits in FY2010 reflects a few accounts related to the ongoing infrastructure projects. However, the majority of deposits are being held in safe financial assets rather than being lent to the private sector. Under the secured transaction act, there has only been a small increase in lending, mainly auto-loans.

\section{The Banking Board's supervision capacity has improved, but would benefit}

from further strengthening. The Banking Board performs on-site supervision with technical assistance from PFTAC. However, staff turnover remains high and newly appointed staff need additional training. Staff supported continued efforts to strengthen onsight monitoring of liquidity policies, compliance with AML laws and loan-loss provisions. Staff also highlighted the importance of operational independence and well-defined legal authority of the Banking Board for prudential regulatory purposes and supported the revision of the Banking Act in this direction.

\section{The staff also recommended that the FSM Development Bank and other non-} deposit taking financial institutions be supervised by the Banking Board. Over half of the loans in the Development Bank are under substandard and doubtful categories, with insufficient provisioning against possible losses. The Development Bank also plans to go beyond the current focus on commercial lending and compete directly with private banks in retail lending. The staff cautioned against under-provisioning for poor-performing loans and potential risk exposures on consumer lending, and reiterated the importance of bringing both credit unions and the Development Bank under appropriate regulation and supervision in line with the international best practices.

27. There is an urgent need to increase the capacity for insurance supervision, especially in the area of captive insurance. ${ }^{5}$ There are currently three captive insurance companies licensed in the FSM, and three more are expected over the coming months. These companies are now supervised by the Insurance Board, which recently separated from the Banking Board. The Insurance Board, however, lacks adequate staffing, data processing

\footnotetext{
${ }^{5}$ Captive insurance company provide insurance or reinsurance for risks of the entity or entities to which it belongs. Captive insurance activities are seen by some as a possible revenue source from licensing fees and taxes.
} 
capacity, and specialized skills to perform effective supervision. The authorities agreed with the need to step up their supervisory capacity and would seek technical assistance from the Fund and other agencies. They also noted the need to strengthen the national tax administrator's capacity to audit foreign corporations.

\section{E. Other Issues}

28. The reliability, coverage, and timeliness of economic statistics need to be improved to guide policies. Domestic capacity to produce economic data in all sectors remains limited, though some progress has been made in the area of balance of payment statistics. In particular, the authorities are encouraged to collect consolidated fiscal data across national and state governments in a timely manner to determine fiscal policy priorities. In addition, collecting remittance data should be given priority in light of continued outward migration.

\section{Staff APpraisal}

29. Growth prospects in the FSM remain weak given the sluggish private sector and the scheduled decline in Compact grants. The FSM's recovery relies mainly on public infrastructure projects, with limited private sector support. While growth could be supported in the short term through the release of delayed infrastructure grants, long-term growth would only be achievable through sound fiscal and structural policies.

\section{The global crisis has increased the urgency of major fiscal and structural}

reforms. The FSM has relied heavily on the amended Compact to advance its economic development and sustain a large public sector. The CTF suffered large losses during the global financial crisis, and is unlikely to generate sufficient income to supplement the expiry of Compact grants in FY2023. Further delays in needed reforms would lead to more costly adjustments in the future.

\section{The fiscal balance has improved, but the need for significant adjustment}

remains. Securing fiscal sustainability will require swift implementation of the planned tax reform and tight expenditure control. Consolidation should begin in FY2011 with the passage of the proposed tax bills at both the national and state levels and further improvements in tax administration. On the expenditure side, the priority is to contain spending, especially in the run-up to the spring elections. A medium-term budgeting framework would also improve expenditure control.

\section{At the same time, reforms to facilitate foreign direct investment would enhance} growth, create new employment, and generate higher revenue. The priorities should be to further liberalize the foreign investment regime, improve project management and procurement of resources, increase the availability of skilled labor through external contracting as well as domestic training, and reduce the large public-private wage gap.

33. Supervision over the financial system should be enhanced. A refocusing of the FSM Development Bank to avoid direct competition with commercial banks would help 
promote the development of the financial system. At the same time, supervision should be extended to cover credit unions and the FSM Development Bank, while insurance supervision should be strengthened, particularly in the growing area of captive insurance.

34. The U.S. dollar remains the appropriate currency for the FSM, given the size of the economy, its close ties to the United States, and limited administrative capacity for independent monetary and exchange rate policies.

35. Improving domestic capacity to compile data is necessary to strengthen monitoring and policy analysis. Fund staff, including through PFTAC, will continue to assist in this area.

36. It is recommended that the next Article IV consultation take place on the 24-month cycle. 
Figure 1. Micronesia: Regional Comparison of Recent Developments

Compared to the PICs, the FSM is one of the few countries that recorded positive growth in FY2009, but inflation remained high. The high current account deficit reflects Compact related spending, and the improvement in fiscal balance is noticeable among the other Pacific Island economies.
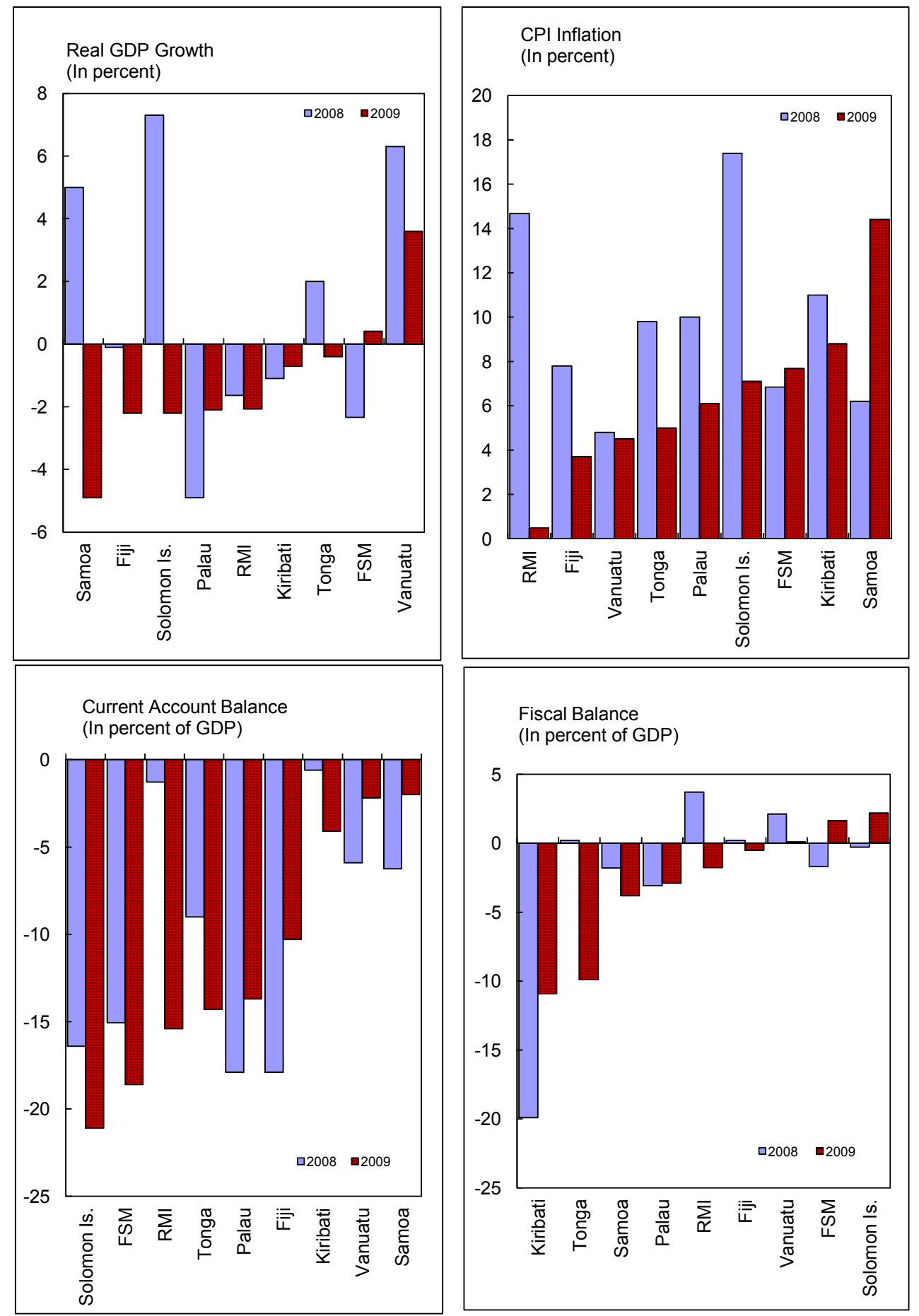

Note: RMI and FSM stand for Republic of Marshall Islands and Federated States of Micronesia, respectively. The charts are sorted by 2009 data.

Source: Fund staff estimates and FSM authorities. 
Figure 2. Micronesia: Macroeconomic Developments

Following the contraction in FY2008, the economy recovered in FY2009. CPI inflation remained high for FY2009, but moderated in the second half of the year. The current account deficit remains high, reflecting high commodity prices and construction related imports. The fiscal balance improved despite the pick up in expenditures.
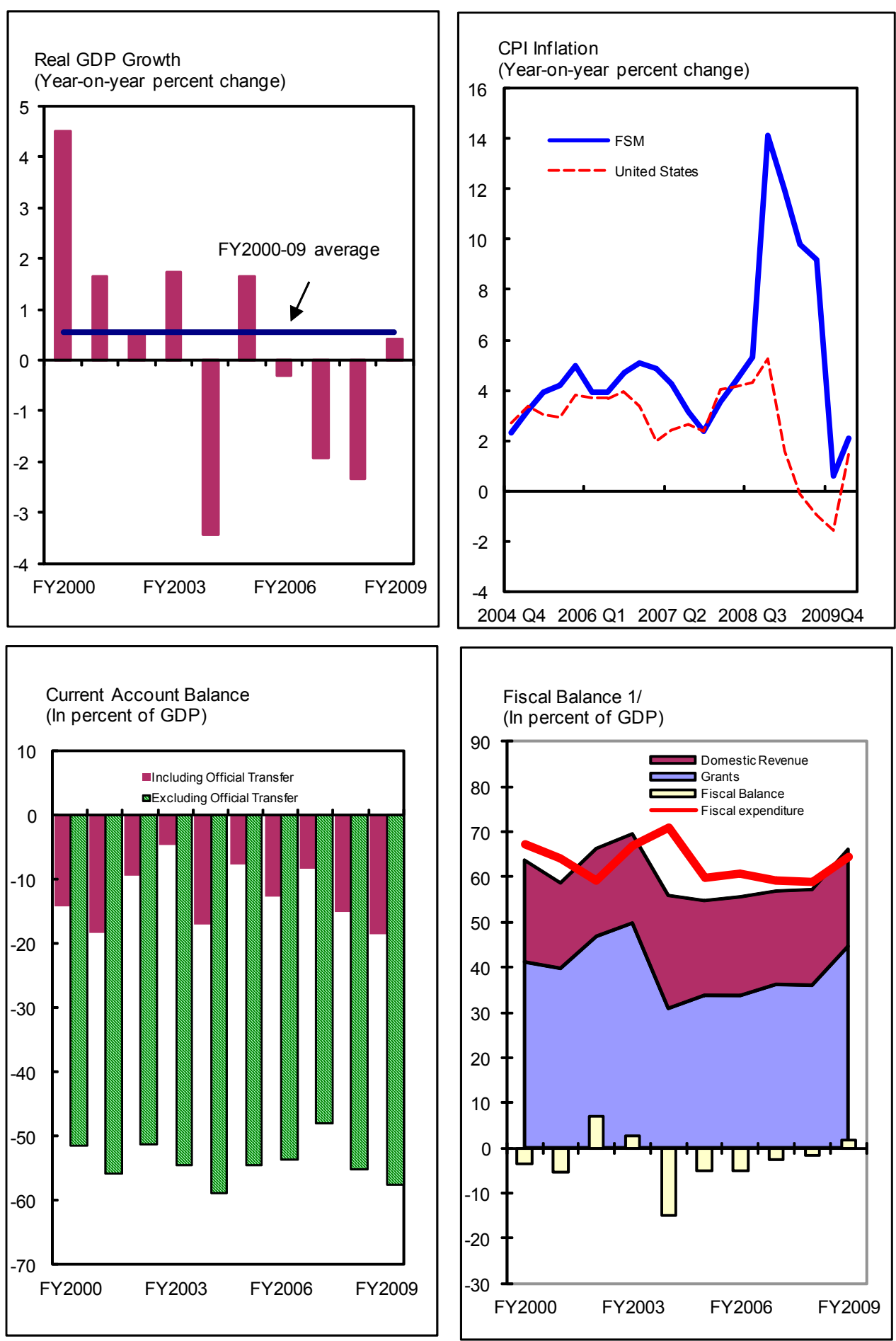

Source: Fund staff estimates and FSM authorities.

$1 /$ Total revenue is sum of grants and domestic revenue (stacked in chart). 
Figure 3. Micronesia: Developments in the Exchange Rate, Export Growth, and Tourism (2000-09)
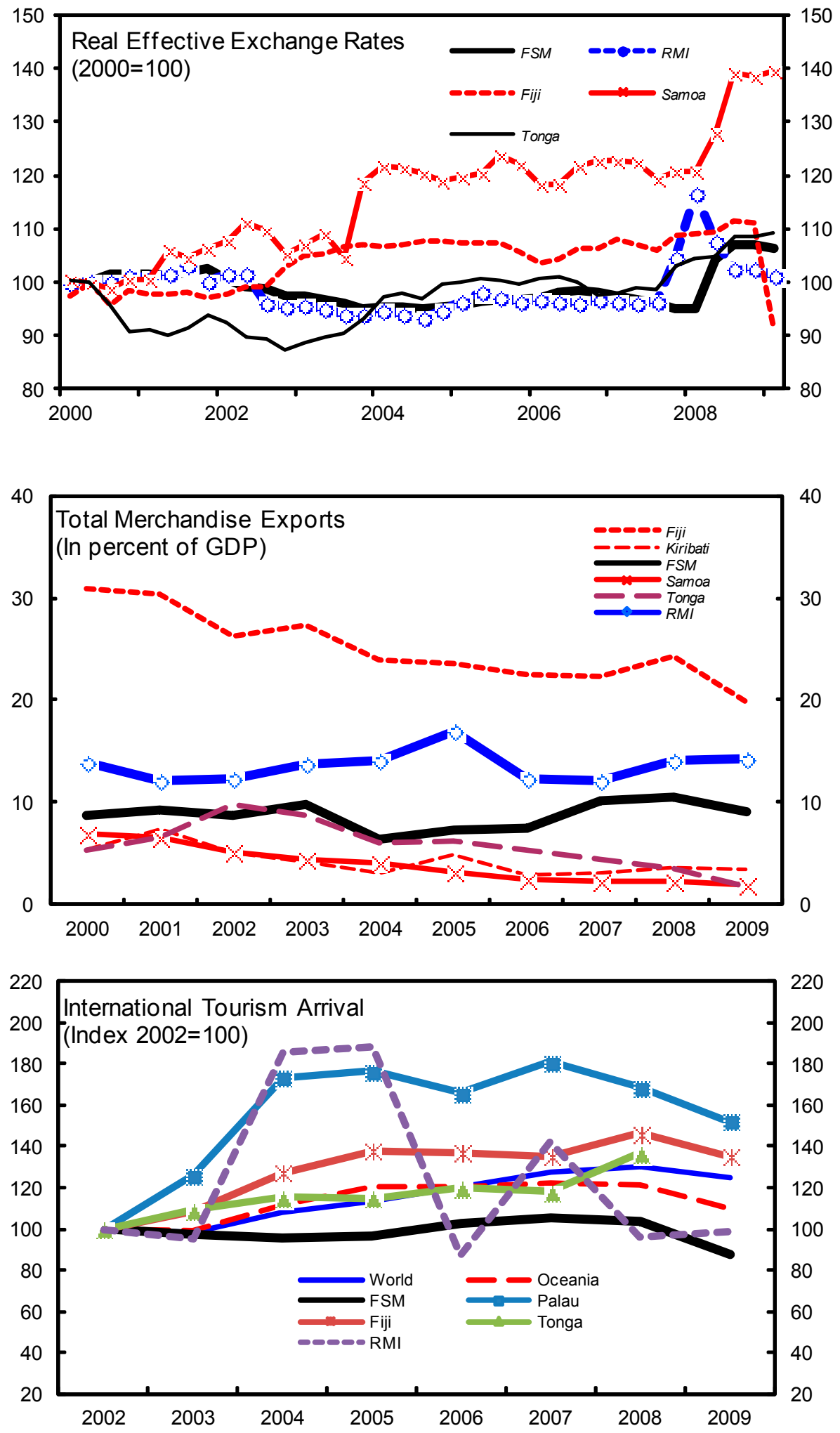

Source: International Financial Statistics, Fund staff estimates, and FSM authorities. 
Table 1. Micronesia: Basic Data, FY2006-11 1/

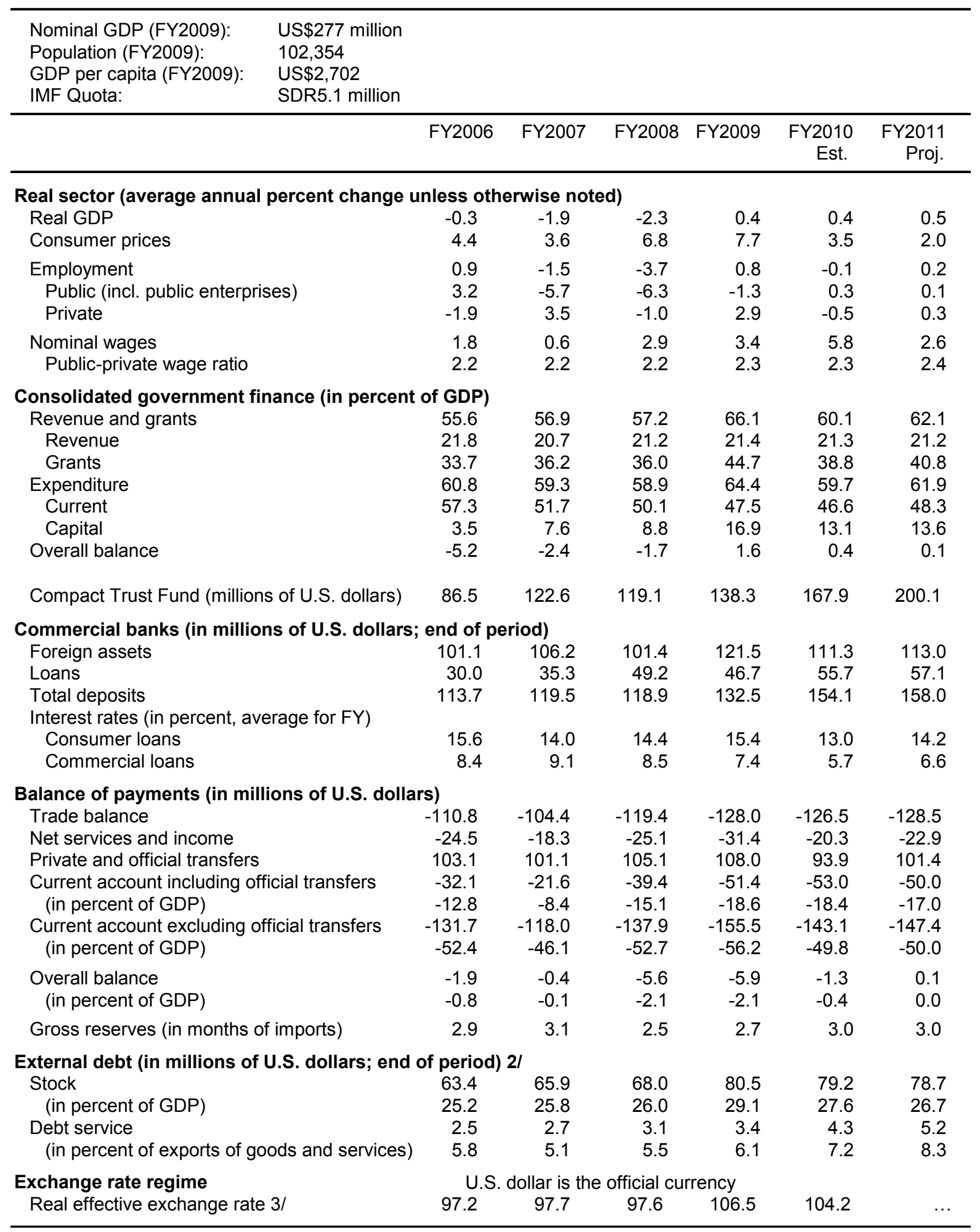

Sources: Data provided by the FSM authorities and Fund staff estimates.

1/ Fiscal year ending September 30. Estimates for FY2010 and projections for FY2011 are preliminary and based on data received from the authorities.

2/ Government and public enterprise debt only.

$3 /$ Year $2000=100$. 
Table 2. Micronesia: General Government Operations, FY2006-10 1/

\begin{tabular}{|c|c|c|c|c|c|}
\hline & FY2006 & FY2007 & FY2008 & FY2009 & $\begin{array}{c}\text { FY2010 } \\
\text { Est. }\end{array}$ \\
\hline & \multicolumn{5}{|c|}{ (In millions of U.S. dollars) } \\
\hline Overall balance & -13.1 & -6.2 & -4.5 & 4.6 & 1.0 \\
\hline Total revenue and grants & 139.7 & 145.4 & 149.8 & 182.8 & 172.7 \\
\hline Revenue & 54.9 & 52.8 & 55.4 & 59.3 & 61.3 \\
\hline Tax revenue & 29.7 & 27.8 & 29.3 & 31.7 & 34.2 \\
\hline Non-tax revenue & 25.2 & 24.9 & 26.1 & 27.6 & 27.1 \\
\hline Fishing access revenue & 13.2 & 15.0 & 17.0 & 20.0 & 18.3 \\
\hline Dividend and interest income & 1.4 & 2.7 & 0.5 & 0.7 & 0.7 \\
\hline Other nontax revenues & 10.6 & 7.2 & 8.6 & 6.8 & 8.1 \\
\hline Grants (from abroad) & 84.8 & 92.6 & 94.3 & 123.5 & 111.4 \\
\hline Current & 79.6 & 79.2 & 79.0 & 84.4 & 73.6 \\
\hline Capital & 5.2 & 13.3 & 15.4 & 39.1 & 37.8 \\
\hline Total expenditure & 152.8 & 151.6 & 154.2 & 178.2 & 171.7 \\
\hline Current & 144.0 & 132.1 & 131.1 & 131.4 & 134.1 \\
\hline Goods and services & 138.4 & 129.0 & 127.5 & 128.9 & 130.6 \\
\hline Wages and salaries & 65.5 & 61.7 & 60.2 & 63.1 & 65.9 \\
\hline Travel & 8.4 & 8.2 & 8.2 & 8.3 & 8.6 \\
\hline Other & 64.5 & 59.0 & 59.1 & 57.5 & 56.1 \\
\hline Subsidies & 1.2 & 2.4 & 2.9 & 2.3 & 3.3 \\
\hline Net transfers & 4.4 & 0.7 & 0.7 & 0.0 & 0.0 \\
\hline Capital & 8.8 & 19.5 & 23.1 & 46.8 & 37.6 \\
\hline Acquisition of fixed capital & 5.0 & 9.1 & 14.7 & 38.0 & 23.0 \\
\hline Multi-purpose development projects & 3.8 & 10.4 & 8.4 & 8.8 & 14.6 \\
\hline Capital Transfers & 0.0 & 0.0 & 0.0 & 0.0 & 0.0 \\
\hline Memorandum items: & \multicolumn{5}{|c|}{ (In percent of GDP) } \\
\hline Overall balance & -5.2 & -2.4 & -1.7 & 1.6 & 0.4 \\
\hline Revenue and Grants & 55.6 & 56.9 & 57.2 & 66.1 & 60.1 \\
\hline Revenue & 21.8 & 20.7 & 21.2 & 21.4 & 21.3 \\
\hline Tax revenue & 11.8 & 10.9 & 11.2 & 11.5 & 11.9 \\
\hline Non-tax revenue & 10.0 & 9.7 & 10.0 & 10.0 & 9.4 \\
\hline Grants & 33.7 & 36.2 & 36.0 & 44.7 & 38.8 \\
\hline Total expenditure & 60.8 & 59.3 & 58.9 & 64.4 & 59.7 \\
\hline Current & 57.3 & 51.7 & 50.1 & 47.5 & 46.6 \\
\hline Capital & 3.5 & 7.6 & 8.8 & 16.9 & 13.1 \\
\hline
\end{tabular}

Sources: Data provided by the FSM authorities and staff estimates.

1/ Fiscal year ending September. The consolidated fiscal accounts cover the national and four state governments. 
Table 3. Micronesia: Indicators of Financial and External Vulnerability, FY2006-10

\begin{tabular}{|c|c|c|c|c|c|}
\hline & FY2006 & FY2007 & FY2008 & FY2009 & FY2010 \\
\hline \multicolumn{6}{|l|}{ Commercial banks } \\
\hline Deposits (Year-on-year percent change) & 2.1 & 5.1 & -0.5 & 11.4 & 16.3 \\
\hline Demand (in millions of U.S.\$) & 27.6 & 32.8 & 27.8 & 31.5 & 34.0 \\
\hline Savings (in millions of U.S.\$) & 51.7 & 47.2 & 54.1 & 70.2 & 88.5 \\
\hline Time (including CDs) (in millions of U.S.\$) & 34.4 & 39.4 & 36.4 & 30.1 & 30.8 \\
\hline Other (in millions of U.S.\$) & 0.1 & 0.1 & 0.6 & 0.7 & 0.8 \\
\hline \multirow{3}{*}{$\begin{array}{l}\text { Loans (Year-on-year percent change) } \\
\text { (in percent of GDP) }\end{array}$} & 16.9 & 17.7 & 39.3 & -5.1 & 19.3 \\
\hline & 11.9 & 13.8 & 18.8 & 16.9 & 19.4 \\
\hline & \multicolumn{5}{|c|}{ (In percent of total assets) } \\
\hline Foreign assets & 76.3 & 76.2 & 69.1 & 74.1 & 62.4 \\
\hline Return on assets $1 /$ & 1.6 & 1.6 & 1.2 & 0.7 & $\ldots$ \\
\hline \multirow[t]{2}{*}{ Equity capital $1 /$} & 10.8 & 11.1 & 10.6 & 10.4 & 9.4 \\
\hline & \multicolumn{5}{|c|}{ (In percent of total loans) } \\
\hline Loss allowance & 4.9 & 4.0 & 5.7 & 6.2 & 3.4 \\
\hline Non-performing loans & 0.9 & 3.3 & 6.0 & 3.2 & 2.8 \\
\hline \multirow{2}{*}{\multicolumn{6}{|c|}{ FSM Development Bank }} \\
\hline & & & & & \\
\hline \multirow{3}{*}{$\begin{array}{l}\text { Loans } \\
\quad \text { (in percent of GDP) }\end{array}$} & 48.6 & 5.4 & -2.0 & 6.2 & -4.5 \\
\hline & 12.9 & 13.3 & 12.7 & 12.8 & 9.5 \\
\hline & \multicolumn{5}{|c|}{ (In percent of total assets) } \\
\hline Foreign assets & 5.8 & 6.4 & 6.5 & 6.2 & 6.0 \\
\hline \multirow[t]{2}{*}{ Return on assets } & 2.4 & 4.7 & -4.6 & 6.6 & 1.2 \\
\hline & \multicolumn{5}{|c|}{ (In percent of total loans) } \\
\hline Loss allowance & 15.3 & 13.7 & 17.3 & 16.9 & 20.3 \\
\hline \multicolumn{6}{|l|}{ External indicators } \\
\hline Exports (goods \& services, y/y percent change) & 8.9 & 24.5 & 6.5 & -1.4 & 6.1 \\
\hline Imports (goods \& services, y/y percent change) & 3.4 & 0.1 & 11.0 & 9.1 & -2.9 \\
\hline \multicolumn{6}{|l|}{ Current account balance (percent of GDP) } \\
\hline Including official transfers & -12.8 & -8.4 & -15.1 & -18.6 & -18.4 \\
\hline Excluding official transfers & -52.4 & -46.1 & -52.7 & -56.2 & -49.8 \\
\hline Overall balance (percent of GDP) & -0.8 & -0.1 & -2.1 & -2.1 & -0.4 \\
\hline \multicolumn{6}{|l|}{ Gross official reserves $2 /$} \\
\hline In millions of U.S. dollars & 47.2 & 49.5 & 45.3 & 53.1 & 56.6 \\
\hline In months of imports of goods and services & 2.9 & 3.1 & 2.5 & 2.7 & 3.0 \\
\hline In percent of GDP & 18.8 & 19.4 & 17.3 & 19.2 & 19.7 \\
\hline \multicolumn{6}{|l|}{ Total external debt $3 /$} \\
\hline In millions of U.S. dollars & 63.4 & 65.9 & 68.0 & 80.5 & 79.2 \\
\hline In percent of exports of goods and services & 147.9 & 123.4 & 119.6 & 143.5 & 133.1 \\
\hline In percent of GDP & 25.2 & 25.8 & 26.0 & 29.1 & 27.6 \\
\hline \multicolumn{6}{|l|}{ Debt service } \\
\hline In millions of U.S. dollars & 2.5 & 2.7 & 3.1 & 3.4 & 4.3 \\
\hline In percent of exports of goods and services & 5.8 & 5.1 & 5.5 & 6.1 & 7.2 \\
\hline In percent of GDP & 1.0 & 1.1 & 1.2 & 1.2 & 1.5 \\
\hline
\end{tabular}

1/ On calendar year basis and data for 2010 as of end-September. The equity capital ratio refers to domestic bank.

2/ Data for 2010 as of end-July.

3 / About 2/3 of the total is concessional debt to the Asian Development Bank. 
Table 4. Micronesia: Balance of Payments, FY2006-10

\begin{tabular}{|c|c|c|c|c|c|}
\hline & FY2006 & FY2007 & FY2008 & FY2009 & $\begin{array}{l}\text { FY2010 } \\
\text { Est. }\end{array}$ \\
\hline & \multicolumn{4}{|c|}{ (In millions of U.S. dollars) } & \\
\hline Overall balance & -1.9 & -0.4 & -5.6 & -5.9 & -1.3 \\
\hline \multirow{2}{*}{$\begin{array}{l}\text { Current Account Balance } \\
\text { Trade balance }\end{array}$} & -32.1 & -21.6 & -39.4 & -51.4 & -53.0 \\
\hline & -110.8 & -104.4 & -119.4 & -128.0 & -126.5 \\
\hline \multirow{2}{*}{ Exports, f.o.b. } & 18.7 & 26.0 & 27.3 & 24.9 & 28.2 \\
\hline & -129.5 & -130.4 & -146.7 & -152.9 & -154.8 \\
\hline Petroleum products & -27.0 & -28.7 & -34.3 & -42.2 & -37.7 \\
\hline Services account & -39.8 & -35.8 & -38.7 & -50.4 & -41.6 \\
\hline Receipts & 24.1 & 27.4 & 29.6 & 31.1 & 31.3 \\
\hline \multirow{2}{*}{$\begin{array}{l}\text { Travel } \\
\text { Communications (net) }\end{array}$} & 20.4 & 22.2 & 24.1 & 25.3 & 25.4 \\
\hline & 1.8 & 1.7 & 1.8 & 1.8 & 1.8 \\
\hline \multirow{2}{*}{$\begin{array}{l}\text { Other } \\
\text { Payments }\end{array}$} & 1.9 & 3.5 & 3.7 & 4.1 & 4.1 \\
\hline & -63.9 & -63.3 & -68.2 & -81.6 & -72.9 \\
\hline Freight and insurance & -20.8 & -21.8 & -23.2 & -25.4 & -25.3 \\
\hline \multirow{2}{*}{$\begin{array}{l}\text { Transportation } \\
\text { Travel }\end{array}$} & -15.9 & -15.0 & -15.4 & -15.7 & -15.7 \\
\hline & -7.1 & -7.2 & -7.3 & -7.6 & -7.9 \\
\hline \multirow{2}{*}{$\begin{array}{c}\text { Other } \\
\text { Income, net }\end{array}$} & -20.2 & -19.3 & -22.4 & -32.8 & -24.0 \\
\hline & 15.3 & 17.5 & 13.6 & 19.0 & 21.3 \\
\hline Receipts & 27.2 & 29.8 & 29.0 & 29.0 & 27.0 \\
\hline \multirow{2}{*}{$\begin{array}{l}\text { Receipts } \\
\text { Fishing rights fees } \\
\text { Interest dividend income }\end{array}$} & 13.3 & 14.8 & 17.0 & 20.4 & 18.3 \\
\hline & 13.9 & 14.9 & 12.0 & 8.5 & 8.7 \\
\hline & -11.9 & -12.2 & -15.4 & -10.0 & -5.7 \\
\hline Foreign workers earnings & -2.2 & -1.5 & -1.6 & -2.2 & -2.2 \\
\hline Interest payments & -1.6 & -1.6 & -1.7 & -2.0 & 2.2 \\
\hline \multirow{2}{*}{$\begin{array}{l}\text { Dividends } \\
\text { Unrequited transfers }\end{array}$} & -8.1 & -9.2 & -12.1 & -5.7 & -5.7 \\
\hline & 103.1 & 101.1 & 105.1 & 108.0 & 93.9 \\
\hline Private & 3.5 & 4.7 & 6.6 & 3.8 & 3.8 \\
\hline Inflows & 14.3 & 15.4 & 17.4 & 18.2 & 18.2 \\
\hline Outflows & -10.8 & -10.7 & -10.8 & -14.4 & -14.5 \\
\hline Official & 99.6 & 96.4 & 98.4 & 104.1 & 90.1 \\
\hline Compact funds & 59.3 & 60.6 & 57.9 & 65.8 & 58.0 \\
\hline Other & 40.3 & 35.8 & 40.5 & 38.3 & 32.0 \\
\hline Capital and financial account & 30.1 & 21.2 & 33.8 & 45.5 & 51.7 \\
\hline Capital Account Balance & 35.0 & 37.3 & 43.2 & 70.1 & 63.1 \\
\hline Capital Transfers, Official & 3.0 & 7.0 & 4.9 & 7.5 & 11.8 \\
\hline Trust Fund Grants & 16.4 & 17.7 & 19.0 & 20.9 & 21.0 \\
\hline Other & 15.5 & 12.6 & 19.3 & 41.6 & 30.4 \\
\hline Financial Account Balance & -4.8 & -16.1 & -9.3 & -24.6 & -11.4 \\
\hline Direct Investment (net) & 0.1 & 0.1 & -5.3 & 0.6 & 0.6 \\
\hline Portfolio investment & -8.2 & -17.3 & -20.0 & -20.9 & -21.0 \\
\hline of which: Contributions to the Trust Fund & -16.4 & -17.7 & -19.0 & -20.9 & -21.0 \\
\hline Other investment (net) & 3.2 & 1.0 & 16.0 & -4.2 & 9.0 \\
\hline Memorandum items & & (In perce & of GDP) & & \\
\hline Current account balance & -12.8 & -8.4 & -15.1 & -18.6 & -18.4 \\
\hline Trade balance & -44.1 & -40.8 & -45.6 & -46.3 & -44.0 \\
\hline Exports & 7.5 & 10.2 & 10.4 & 9.0 & 9.8 \\
\hline Imports & -51.5 & -51.0 & -56.0 & -55.3 & -53.9 \\
\hline Service & -15.8 & -14.0 & -14.8 & -18.2 & -14.5 \\
\hline Income & 6.1 & 6.9 & 5.2 & 6.9 & 7.4 \\
\hline Transfers & 41.0 & 39.6 & 40.1 & 39.0 & 32.7 \\
\hline Private & 1.4 & 1.9 & 2.5 & 1.4 & 1.3 \\
\hline Official & 39.6 & 37.7 & 37.6 & 37.6 & 31.3 \\
\hline Current account, ex. transfers & -53.8 & -48.0 & -55.2 & -57.6 & -51.1 \\
\hline Overall balance & -0.8 & -0.1 & -2.1 & -2.1 & -0.4 \\
\hline
\end{tabular}

Sources: Data provided by the FSM authorities, and Fund staff estimates. 
Table 5. Micronesia: Medium-term Scenario (Current Policies), FY2007-15 1/

\begin{tabular}{|c|c|c|c|c|c|c|c|c|c|}
\hline & FY2007 & FY2008 & FY2009 & $\begin{array}{l}\text { FY2010 } \\
\text { Est. }\end{array}$ & $\begin{array}{l}\text { FY2011 } \\
\text { Proj. }\end{array}$ & $\begin{array}{l}\text { FY2012 } \\
\text { Proj. }\end{array}$ & $\begin{array}{l}\text { FY2013 } \\
\text { Proj. }\end{array}$ & $\begin{array}{l}\text { FY2014 } \\
\text { Proj. }\end{array}$ & $\begin{array}{c}\text { FY2015 } \\
\text { Proj. }\end{array}$ \\
\hline \multicolumn{10}{|l|}{ Real sector } \\
\hline Real GDP (percent change) & -1.9 & -2.3 & 0.4 & 0.4 & 0.5 & 0.6 & 0.6 & 0.6 & 0.6 \\
\hline Consumer prices (percent change) & 3.6 & 6.8 & 7.7 & 3.5 & 2.0 & 2.0 & 2.0 & 1.9 & 1.9 \\
\hline \multicolumn{10}{|l|}{ General government finance (in percent of GDP) } \\
\hline Revenue and grants & 56.9 & 57.2 & 66.1 & 60.1 & 62.1 & 61.9 & 60.7 & 59.7 & 58.7 \\
\hline Total domestic revenue & 20.7 & 21.2 & 21.4 & 21.3 & 21.2 & 21.1 & 21.0 & 20.9 & 20.8 \\
\hline Grants & 36.2 & 36.0 & 44.7 & 38.8 & 40.8 & 40.7 & 39.7 & 38.8 & 37.9 \\
\hline Expenditure & 59.3 & 58.9 & 64.4 & 59.7 & 61.9 & 61.5 & 60.4 & 59.3 & 58.3 \\
\hline Current & 51.7 & 50.1 & 47.5 & 46.6 & 48.3 & 46.6 & 45.9 & 45.2 & 44.5 \\
\hline Capital & 7.6 & 8.8 & 16.9 & 13.1 & 13.6 & 14.9 & 14.5 & 14.2 & 13.8 \\
\hline Overall balance & -2.4 & -1.7 & 1.6 & 0.4 & 0.1 & 0.3 & 0.3 & 0.4 & 0.4 \\
\hline $\begin{array}{l}\text { Compact Trust Fund } \\
\text { (in millions of US\$; end of period) }\end{array}$ & 122.6 & 119.1 & 138.3 & 167.9 & 200.1 & 235.3 & 273.7 & 315.7 & 361.4 \\
\hline \multicolumn{10}{|l|}{ Balance of payments (in millions of U.S. dollars) } \\
\hline Trade balance & -104.4 & -119.4 & -128.0 & -126.5 & -128.5 & -130.6 & -132.7 & -134.9 & -137.0 \\
\hline Net services & -35.8 & -38.7 & -50.4 & -41.6 & -44.3 & -45.3 & -45.9 & -46.4 & -46.9 \\
\hline Net income & 17.5 & 13.6 & 19.0 & 21.3 & 21.5 & 22.3 & 23.2 & 24.2 & 25.2 \\
\hline Private and official transfers & 101.1 & 105.1 & 108.0 & 93.9 & 101.4 & 97.1 & 97.5 & 98.0 & 98.9 \\
\hline Current account & -21.6 & -39.4 & -51.4 & -53.0 & -50.0 & -56.4 & -57.9 & -59.1 & -59.8 \\
\hline (In percent of GDP) & -8.4 & -15.1 & -18.6 & -18.4 & -17.0 & -18.7 & -18.7 & -18.6 & -18.3 \\
\hline Current account excluding official transfers & -118.0 & -137.9 & -155.5 & -143.1 & -147.4 & -149.4 & -151.0 & -152.4 & -153.8 \\
\hline (In percent of GDP) & -46.1 & -52.7 & -56.2 & -49.8 & -50.0 & -49.4 & -48.7 & -47.9 & -47.1 \\
\hline \multicolumn{10}{|l|}{ External debt (in millions of US\$; end of period) 2/ } \\
\hline Stock & 65.9 & 68.0 & 80.5 & 79.2 & 78.7 & 78.2 & 77.6 & 77.0 & 76.3 \\
\hline (in percent of GDP) & 25.8 & 26.0 & 29.1 & 27.6 & 26.7 & 25.8 & 25.0 & 24.2 & 23.4 \\
\hline Debt service & 2.7 & 3.1 & 3.4 & 4.3 & 5.2 & 5.1 & 5.0 & 5.1 & 5.0 \\
\hline (in percent of exports of goods and services) & 5.1 & 5.5 & 6.1 & 7.2 & 8.3 & 7.8 & 7.4 & 7.1 & 6.7 \\
\hline
\end{tabular}

Sources: the FSM authorities and Fund staff estimates.

1/ Estimates for FY2010 and projections from FY2011-15 are preliminary and based on data received from the authorities.

2/ Government and public enterprise debts only. 
Table 6. Micronesia: Social Indicators

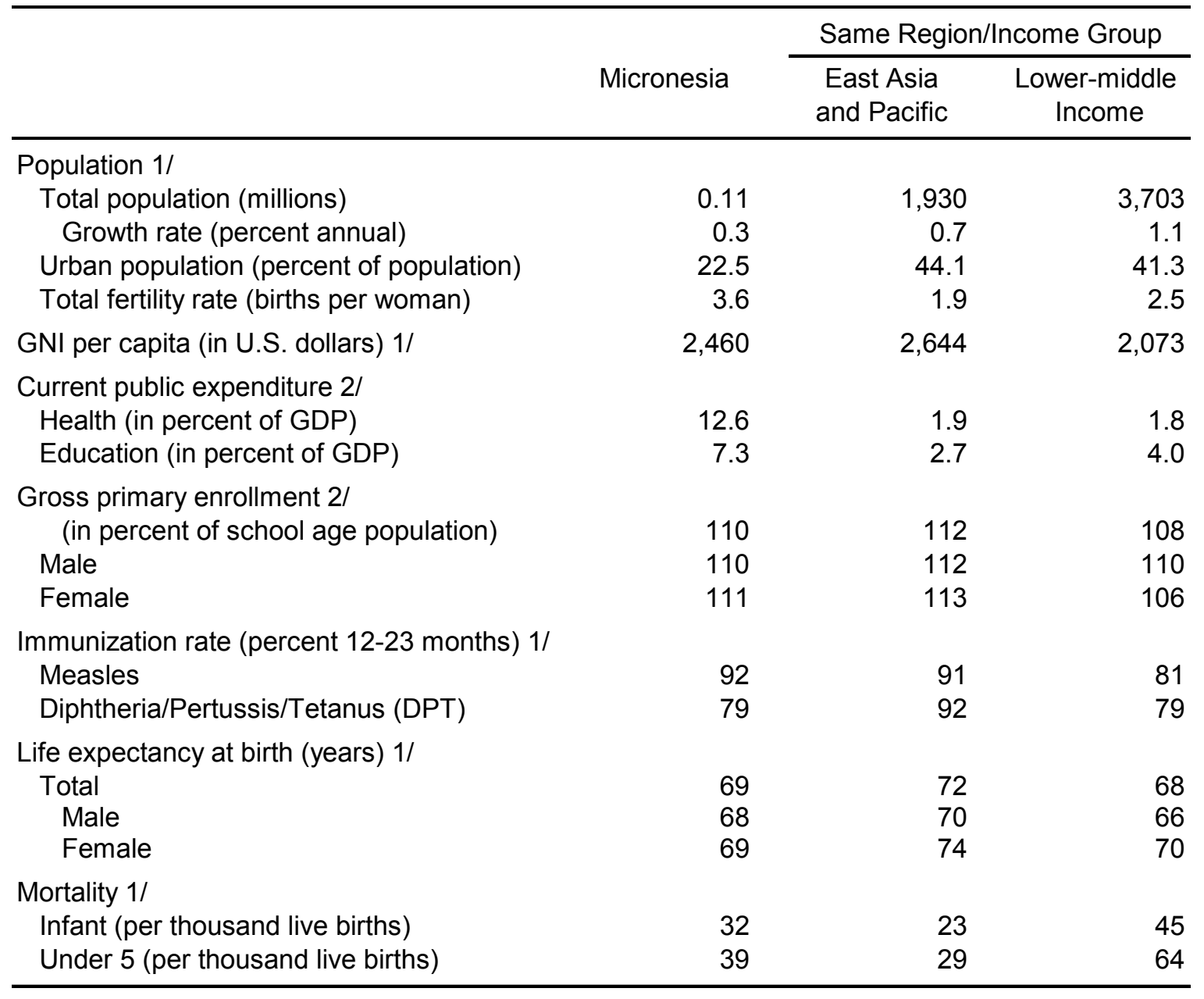

Sources: World Development Indicators 2008 and Millenium Development Goals, World Bank.

$1 /$ Data as of 2008.

2/ Data as of 2007 or latest available. 


\section{APPENDIX I: MICRONESIA-LONG-TERM FISCAL SUSTAINABILITY}

This appendix assesses the FSM's long-term fiscal sustainability, updating the estimates in the 2008 Article IV consultation. The analysis considers implications of the expected expiry of annual Compact grants on the fiscal sustainability of FSM. It rests on a broader perspective than what the amended Compact agreement envisages in the sense that it looks at the general self-reliance of the FSM government and incorporates also a case where the Compact Trust Fund (CTF) would need to offset a possible loss of non-sector grants such as the Supplementary Education Grants (SEG) under the amended Compact. ${ }^{1}$ Fiscal sustainability is measured by the usable government's asset position as of FY2023 that would generate an investment income large enough to supplement the expiring Compact grants without significantly disrupting public services and eroding the Trust Fund value.

The global financial turmoil has put a heavy toll on the financial performance of the CTF. Net return on assets fell by a cumulative 17 percent over FY2008 - 09. As a result, the market value of the CTF fell substantially, before recovering to about $\$ 168$ million as of endFY2010.

The assessment of the long-term fiscal outlook considers two scenarios. The baseline scenario features limited fiscal adjustment and structural reforms, while an alternative scenario considers comprehensive fiscal reforms, including swift implementation of tax reforms by mid-2011, structural reforms, and better utilization of Compact infrastructure grants. The alternative scenario also considers the costs of a delay in the tax reform implementation.

\section{Baseline scenario}

The baseline scenario assumes that the recent pickup in the fiscal surplus will gradually decline and eventually reach a small surplus of about 0.4 percent of GDP, as expenditure adjusts to the Compact step-down. Medium-term real growth is expected to be low at 0.6 percent, reflecting sluggish investment, continued outmigration, and low productivity growth. Net investment returns on the CTF are expected to be at 6 percent on average thereafter, in line with an earlier GAO study.

Under the baseline, the Trust Fund would not generate sufficient investment income to replace the annual Compact grants expiring in FY2023. By end-FY2023, the stock of financial assets would be about $\$ 800$ million (in FY2010 dollars), of which $\$ 723$ million would be in the CTF and about $\$ 77$ million in other funds. ${ }^{2}$ During the drawdown phrase beginning FY2024, investment income would only be about $\$ 48$ million per year. On the other hand, Compact sector grants in FY2024 are estimated to be $\$ 65$ million, leaving a shortfall of about 6 percent of FY2010 GDP. The shortfall would be even larger at over

\footnotetext{
${ }^{1}$ The Compact Trust Fund in FSM was created to contribute to the long-term budgetary self-reliance of the FSM and to provide the FSM government with an ongoing source of revenue after FY2023. The amended Compact and their subsidiary agreements contain no commitments, either express or implied, regarding the level of the revenue that will be generated by the Trust Funds, nor is there any commitment regarding the degree to which the revenue will contribute to the long-term budgetary self-reliance of the FSM.

${ }^{2}$ All numbers reported here are in millions of USD based on 2010 prices, unless otherwise stated.
} 
10 percent of GDP if the Supplemental Education Grants (SEG) is discontinued after FY2023. With no firm commitment of grants beyond FY2023 and lack of vibrant private sector activity, the government would be forced to either sharply cut expenditures or rapidly deplete its accumulated savings.

Higher investment returns could narrow the shortfall, but are unrealistic over a long horizon. To generate sufficient investment income to offset the expiring Compact grants, the net investment returns would need to be as high as 7.2 percent per year until FY2023, which would require a riskier and more aggressive investment strategy inappropriate for sound public finance management.

\section{Alternative scenario}

Fiscal sustainability can be achieved through significant fiscal adjustment and structural reforms to promote private-sector growth. In an alternative scenario, the government would fortify the recent fiscal surplus by accumulating the savings (e.g., through contribution to the Compact Trust Fund), and undertaking cuts in wasteful current expenditures. The authorities could also swiftly implement the tax reform as scheduled by mid-2011, thereby improving tax revenue by about 3 percent of GDP according to the PFTAC preliminary estimates (text chart). In parallel, structural reforms (e.g., improved education, and other development needs) and better utilization of infrastructure funds could boost potential growth to about $2 \frac{1}{2}$ percent in the medium term despite fiscal consolidation. Net investment returns are assumed to be identical to the baseline at 6 percent per annum. The estimates indicate that long-

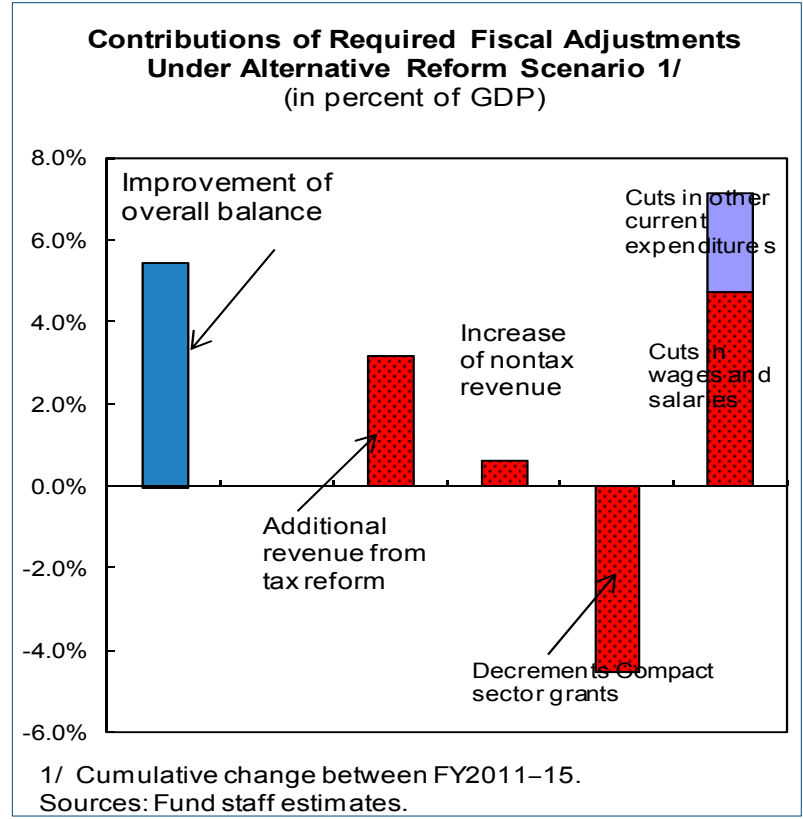
term fiscal sustainability would be achieved by gradually improving fiscal balance (frontloaded) by about 1.1 percent of GDP per annum for five years to reach 5.8 percent of GDP in FY2015, and maintaining that level until FY2023. The budget would return to the path under the baseline scenario after FY2023.

In the alternative scenario, the stock of government assets (including cumulative earnings from these fiscal surpluses) would reach about $\$ 1.1$ billion by the end of the Compact period in FY2023, thus generating sufficient income to offset the expiring Compact grants. Additional savings would be required to reach a higher asset level to generate additional income if supplementing the SEG as well. The required fiscal adjustment is higher than that in the 2008 Article IV Staff Report by about 2 percentage points of GDP (see text charts). The difference reflects the significant decline of the CTF asset value during the financial crisis, which more than offset the modest public savings since then. 


\begin{tabular}{|c|c|c|c|c|}
\hline \multirow[b]{2}{*}{ Scenarios } & \multirow{2}{*}{$\begin{array}{c}\begin{array}{c}\text { Medium-term } \\
\text { overall fiscal } \\
\text { balance }\end{array} \\
\text { in percent of } \\
\text { GDP }\end{array}$} & \multirow{2}{*}{$\begin{array}{l}\text { Total required } \\
\text { adjustment } 1 / \\
\text { in percent of } \\
\text { GDP }\end{array}$} & \multicolumn{2}{|c|}{$\begin{array}{l}\text { Average annual fiscal } \\
\text { adjustment } 1 /\end{array}$} \\
\hline & & & $\begin{array}{l}\text { in percent } \\
\text { of GDP }\end{array}$ & $\begin{array}{l}\text { in USD millions } \\
\text { (2010 prices) }\end{array}$ \\
\hline 1 Baseline scenario: no policy change & 0.4 & - & - & - \\
\hline \multicolumn{5}{|l|}{$\begin{array}{l}2 \text { Alternative reform scenario } 1 / \\
\text { a) Swift tax reforms implementation, } \\
\text { accompanied by structural reforms and } \\
\text { better utilization of infrastructure funds. }\end{array}$} \\
\hline $\begin{array}{l}\text { b) Delay in tax reforms by one year to mid- } \\
\text { FY2012 }\end{array}$ & 6.3 & 6.2 & 1.5 & 5.0 \\
\hline \multicolumn{4}{|l|}{ Memorandum items: } & 1.3 \\
\hline \multicolumn{5}{|c|}{$\begin{array}{l}\text { 1/ Required fiscal adjustments to supplement Compact sector grants (excluding SEG and audit grants) } \\
\text { without significantly disrupt public services when those grants expire by FY2024. }\end{array}$} \\
\hline Source: Fund staff estimates. & & & & \\
\hline
\end{tabular}

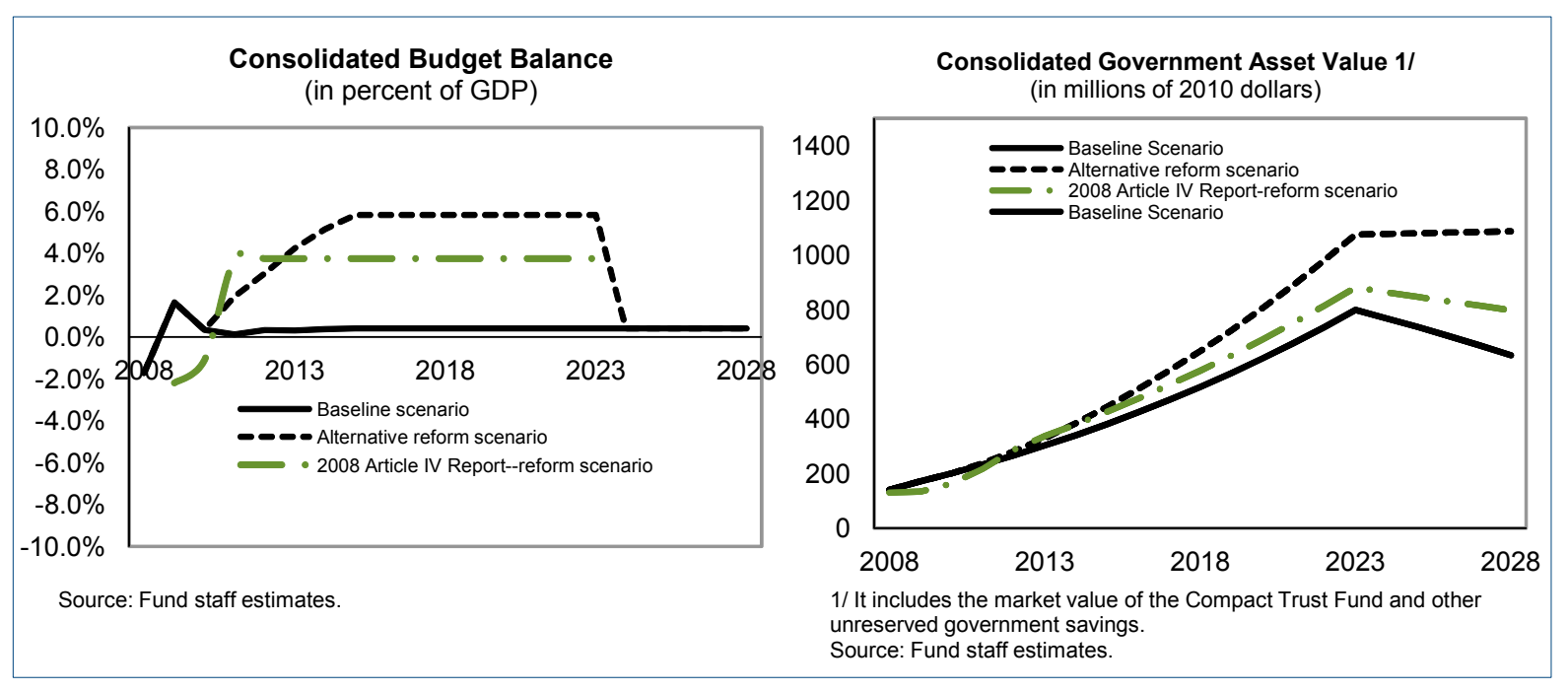

Under the federal system in the FSM, each state would need to supplement the CTF returns with its own fiscal savings. Staff estimates suggest that all states would need to undertake fiscal reforms; however, the size of the required adjustment differs across states according to their initial deficits and stock of financial assets (text table). For example, the state government in Pohnpei would need to improve fiscal balance by about $\$ 7$ million from its position in FY2010, possibly through public payroll reduction and tax reforms. 
Table 2. Recommendations for Medium-term Budget Adjustments

\begin{tabular}{|c|c|c|c|c|c|}
\hline & \multicolumn{3}{|c|}{ Fiscal balance } & \multirow{2}{*}{\multicolumn{2}{|c|}{$\begin{array}{l}\text { Fiscal surpluses (in } \\
\text { FY2010 prices) } \\
\text { FY2015 } \\
\text { Proj. }\end{array}$}} \\
\hline & \multirow{2}{*}{$\begin{array}{l}\text { FY2009 } \\
\text { in USD } \\
\text { millions }\end{array}$} & \multicolumn{2}{|c|}{$\begin{array}{c}\text { FY2010 } \\
\text { Est. }\end{array}$} & & \\
\hline & & $\begin{array}{l}\text { in USD } \\
\text { millions }\end{array}$ & $\begin{array}{l}\text { in percent } \\
\text { of GDP }\end{array}$ & $\begin{array}{l}\text { in USD } \\
\text { millions }\end{array}$ & $\begin{array}{l}\text { in percent } \\
\text { of GDP }\end{array}$ \\
\hline National government & 5.4 & 2.0 & 0.7 & 2.7 & 0.9 \\
\hline Chuuk & 2.5 & 0.4 & 0.1 & 4.3 & 1.4 \\
\hline Kosrae & 0.4 & 0.1 & 0.0 & 1.0 & 0.3 \\
\hline Pohnpei & -1.3 & -0.3 & -0.1 & 6.7 & 2.2 \\
\hline Yap & -2.4 & -1.2 & -0.4 & 2.7 & 0.9 \\
\hline FSM (consolidated basis) & 4.6 & 1.0 & 0.4 & 17.4 & 5.8 \\
\hline Memorandum item: & & & & & \\
\hline Nominal GDP & 276.5 & 287.4 & & 303.3 & \\
\hline
\end{tabular}

\subsection{Alternative scenario but with delays in tax reforms}

\section{Delays in implementing tax reforms would} increase the fiscal adjustments needed to reach sustainability. If the implementation of tax reforms delayed by one year (until mid2012), the medium term fiscal surplus needed to achieve the sustainability (6.3 percent of GDP) would be higher than the original alternative scenario by about $1 / 2$ percentage points, thus requiring even more challenging adjustments (See text chart).

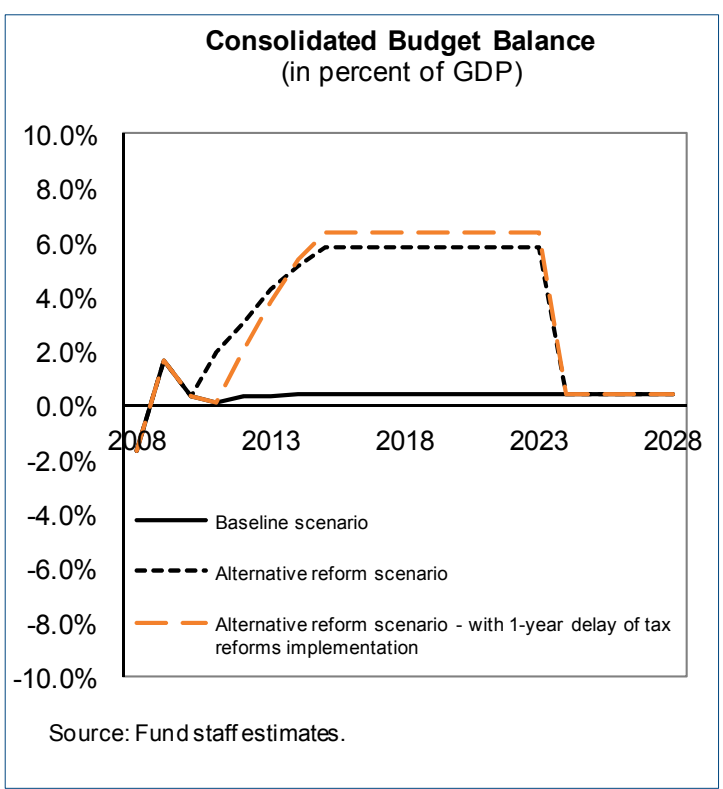




\section{INTERNATIONAL MONETARY FUND \\ FEDERATED STATES OF MICRONESIA \\ Staff Report for the 2010 Article IV Consultation-Informational Annex \\ Prepared by the Asia and Pacific Department \\ (In consultation with other departments)}

December 22, 2010

Contents Page

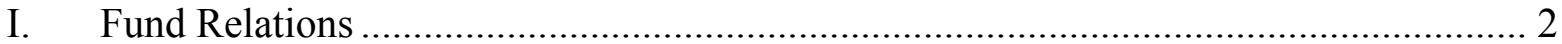

II. Relations with the Pacific Financial Technical Assistance Center (PFTAC) ................ 3

III. Relations with the Asian Development Bank (AsDB) ......................................... 5

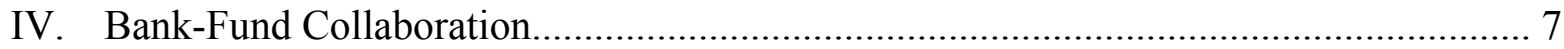

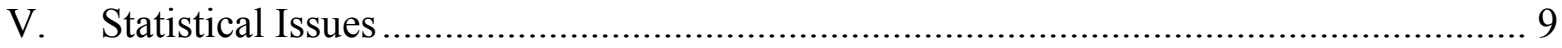




\section{AnNex I. Federated States of Micronesia: Fund Relations}

(As of November 30, 2010)

I. Membership Status: Joined June 24, 1993; accepted Article VIII.

II. General Resources Account:

Quota

Fund holdings of currency

Reserve position in Fund

III. SDR Department:

Net cumulative allocation Holdings
SDR Million

5.10

5.10

0.00

SDR Million

4.81

6.20
Percent Quota

100.00

100.00

0.01

Percent Allocation 100.00

129.08

IV. Outstanding Purchases and Loans: None.

V. Financial Arrangements: None.

VI. Projected Obligations to Fund: None.

VII. Exchange Rate Arrangement:

The U.S. dollar is legal tender and the official currency. The Federated States of Micronesia (FSM) maintains an exchange system that is free of restrictions on international payments and transfers for current and capital transactions except for security reasons.

VIII. Article IV Consultation:

The FSM is on the 24-month consultation cycle. The 2008 Article IV consultation discussions took place during November 12-21, 2008. The Executive Board discussed the staff report (Country Report No. 09/81) and concluded the consultation on February 25, 2009.

IX. Technical Assistance, 1999-2010:

STA, MCM, LEG, and PFTAC have provided technical assistance on statistics, banking supervision, tax policy, and combating of financial crime and financial system abuse.

X. Resident Representative: Mr. Yongzheng Yang assumed his duties as the Resident Representative for Pacific Island Countries on September 13, 2010. He is based in Suva, Fiji. 


\section{AnNeX II. Federated States OF MiCRONESia-Relations With the \\ Pacific Financial Technical Assistance Center (PFTAC) ${ }^{8}$}

Since 2000, the Center's assistance to the FSM has included 30 advisory missions, mostly in the areas of tax policy and administration, financial sector supervision, and statistics. The FSM has also sent a number of officials to various regional seminars and workshops organized by PFTAC.

\section{Tax Administration and Policy}

PFTAC designed a comprehensive tax reform program to help FSM improve the effectiveness of its tax regime and raise additional revenue. In 2005, the President approved recommendations of the Tax Reform Task Force and established an Executive Steering Committee to manage the reform process. The FSM authorities are currently discussing the legislation drafts prepared by IMF Legal Department. PFTAC has provided assistance in revenue estimation, communications and IT strategies, and continues to provide assistance on tax administration improvements and project management.

PFTAC has also participated in customs modernization program including development and implementation of the PC Trade computer software system and provided related TA to facilitate trade, speed up clearances, and improve data accuracy.

\section{Financial Sector Regulation and Supervision}

In May 2006, a PFTAC advisor visited FSM to review draft insurance legislation. An aide memoire was provided to authorities on the supervision of insurance in FSM. The mission discussed and reviewed the proposed insurance legislation and followed up on aspects of issues identified in an IMF technical assistance (TA) mission in March 2006. The Commissioner was cognizant of the need to establish a legislative and supervisory framework for insurers, domestic and foreign, which are active in FSM. Subsequently, a peripatetic expert was assigned by the Monetary and Capital Markets Department (MCM) to the FSM to provide assistance to the Commissioner in insurance regulation and supervision. In addition to the peripatetic advisor on insurance regulation and supervision, the PFTAC advisor also visited the FSM in April 2008. The PFTAC advisor provided assistance to the Commissioner in a number of areas, including drafting proposed regulations for the supervision of captive insurance companies, reviewing and making recommendations regarding applications submitted by a foreign bank to expand the number of branch offices in the FSM, and providing training in off-site bank supervision to Commissioner's staff. In

\footnotetext{
${ }^{8}$ The Pacific Financial Technical Assistance Center (PFTAC) in Suva, Fiji is a multi-donor technical assistance institution, financed by IMF, AsDB, AusAID and NZAID, with the IMF as Executing Agency. The Centre's aim is to build skills and institutional capacity for sustained economic development. Member countries are: Cook Islands, Federated States of Micronesia, Fiji, Kiribati, Marshall Islands, Nauru, Niue, Palau, Papua New Guinea, Samoa, Solomon Islands, Tokelau, Tonga, Tuvalu, and Vanuatu. This annex is prepared on the basis of the input from the PFTAC staff.
} 
September 2010, the PFTAC advisor provided assistance and training to Banking Board staff in conducting an on-site bank examination. Assistance activities included providing guidance and training the completion of examination procedures for assessing the adequacy of branch liquidity policies, verifying the accuracy of prudential returns, assessing the adequacy of the compliance with AML laws and policies, and credit risk practices. Guidance was also provided to the supervision staff in the preparation of appropriate comments documenting apparent violations of laws and regulations. The PFTAC advisor continues to liaise closely with the authorities as needed.

\section{Economic and Financial Statistics}

A workshop on National Accounts was conducted in October 2006 by the PFTAC Statistics Advisor and an expert. Wider macroeconomic statistics issues were also covered briefly, and an outreach program involving education of officials in the four state governments of the importance and uses of macroeconomic statistics was conducted.

The PFTAC Statistics Advisor undertook a TA mission to Pohnpei during October 2008 to improve the national accounts statistics. During the mission, the advisor completed a review of the latest current and constant price GDP estimates. A number of improvements were proposed, including in the coverage of the informal sector and subsistence activities and use of more appropriate price deflators and volume indicators. In addition, a number of recommendations were made to further strengthen the national accounts methodology and source data. The mission concluded that at this stage, producing estimates of GDP using production and expenditure approaches as well as gross value added (GVA) by industry is not feasible due to source data limitations. On-the-job training in compilation of GDP using the income method was also provided as part of the review process of data sources and compilation spreadsheets.

An expert provided by PFTAC undertook a TA mission during May 2009 to improve the balance of payments statistics. The mission reviewed source data, methodology and processes and made a number of recommendations for improvement. On-job training was provided.

FSM participated in a regional national accounts training seminar conducted in Fiji in July 2009 and a regional BOP course in Fiji from November to December 2010. 


\section{AnNeX III. Federated States OF MiCRONESIA-RElations With THE ASIAN DEVELOPMENT BANK (ASDB) ${ }^{1}$}

The Federated States of Micronesia (FSM) became a member of the AsDB in 1990, and has received a substantial amount of assistance since that time. As at December 2009, the FSM has received eight loans, 1 grant, and 43 TA grants. ${ }^{2}$

The AsDB has assisted the FSM by (i) supporting good governance, with a particular focus on economic management and accountability; (ii) ensuring inclusive social development; and (iii) promoting sustained private sector-led economic growth. The approach of the ADB has been to focus on a few key constraints: careful analysis of the political economy; a preparedness to closely manage and support operations; a move away from complex federally administered and state delivered multistate and multisector projects; adoption of home grown solutions; and simple and realistic project outcomes.

Under AsDB's country operations business plan for 2011-13 special attention will be given to supporting infrastructure development, especially power sector development and transport. Support to the energy sector will reduce heavy reliance on fossil fuels, through renewable energy in the form of hydropower, solar energy, and wind energy. Emphasis will be placed on the need for institutional and tariff reform supported by full cost recovery at Utility and State level.

Currently there are two active loans. The Omnibus Infrastructure Development project loans (totaling $\$ 19 \mathrm{~m}$ ), approved in 2004, are designed to enhance public health, environmental quality, and surface water quality through improved wastewater infrastructure and management for Pohnpei and improved delivery of water services and expanded water supply systems for Yap and Kosrae; and improved management and provision of power in Chuuk.

AsDB's non-lending program has focused on improving public sector efficiency, effectiveness, and accountability, as well as raising public awareness through community consultation and participation programs, particularly in Chuuk and Kosrae. Further Technical assistance will be provided to provide for capacity building in project management and procurement processes to support infrastructure development.

\footnotetext{
${ }^{1}$ Prepared on the basis of information from AsDB staff.

${ }^{2}$ The eight loans are for: (i) fisheries development; (ii) law, economic management and public policy; (ii) water supply and sanitation; (iv) basic social services; and (v) private sector development. No loans to FSM in 2008-2010.
} 
Table 1. Loans to the Federated States of Micronesia by Sector

(In millions of U.S. dollars; as of December 2009)

\begin{tabular}{lrr}
\hline Sector & No. & Amount \\
\hline Agriculture and Natural Resources & 1.0 & 6.5 \\
Energy & 0.0 & 0.0 \\
Industry and Nonfuel Minerals & 0.0 & 0.0 \\
Transportation & 0.0 & 0.0 \\
Communications & 0.0 & 0.0 \\
Law, Economic Management and Public Policy & 3.0 & 31.0 \\
Water Supply, Sanitation \& Waste Management & 1.0 & 10.6 \\
Multisector & 3.0 & 27.0 \\
Other & 0.0 & 0.0 \\
Total & 8.0 & 75.1 \\
Memorandum Item: & & \\
Technical Assistance Provided & 43 & 25.0 \\
\hline
\end{tabular}

Table 2. Loan Approvals and Disbursements to the FSM, 2000-09 (In millions of U.S. dollars)

\begin{tabular}{|c|c|c|c|c|c|c|c|c|c|c|c|}
\hline & 2000 & 2001 & 2002 & 2003 & 2004 & 2005 & 2006 & 2007 & 2008 & 2009 & $\begin{array}{c}\text { Total } \\
1990-2009\end{array}$ \\
\hline Loan Approvals & 8.0 & 13.0 & 0.0 & 0.0 & 19.0 & 0.0 & 0.0 & 0.0 & 0.0 & 0.0 & 75.1 \\
\hline Loan Disbursements & 4.4 & 2.5 & 1.4 & 2.7 & 1.1 & 1.7 & 2.5 & 3.6 & 3.6 & 0.8 & 42.1 \\
\hline $\begin{array}{l}\text { Undisbursed balance } \\
\text { at the end of the year }\end{array}$ & 14.2 & 23.3 & 22.0 & 19.2 & 18.1 & 16.4 & 13.9 & 10.3 & 6.8 & 6.0 & ... \\
\hline $\begin{array}{l}\text { Memorandum Item: } \\
\text { TA approvals }\end{array}$ & 0.8 & 1.2 & 1.0 & 1.2 & 0.85 & 0.0 & 0.6 & 0.4 & 0.8 & 0.0 & 25.0 \\
\hline
\end{tabular}




\section{ANNEX IV: BANK-Fund COLlaboration}

37. The Bank and the Fund country teams maintain a close working relationship and have an ongoing dialogue on a range of macroeconomic and structural issues.

38. The teams agreed that FSM's main macroeconomic challenges are to reduce its high dependency on the Compact support from the U.S., which is due to expire in FY2023, while enhancing the prospects for private sector development. To achieve these goals, FSM needs to undertake a decisive fiscal reform as well as to improve business environment.

39. Based on this shared assessment, the teams identified the following structural reform areas as macro-critical, in view of their central role in achieving fiscal consolidation and sustained growth:

(i) Comprehensive revenue reform. FSM collects little revenue from its income and sales taxes, compared with other Pacific Island countries. The government's tax reform package, which includes the introduction of VAT and the net pr ofits tax, and establishment of the Unified Revenue Authority (URA), is yet to pass the Congress, behind the schedule by more than 1 year. The successful tax reform would also benefit the private sector by improving efficiency.

(ii) Reform of the state-owned enterprises (SOEs). SOEs put a significant burden on FSM's budget, while possibly crowding out private firms. They pay higher wages than in the private sector, receive subsidized government loans, and are not subject to the gross revenue tax. The government has taken some steps, including the shutdown of insolvent enterprises such as the National Fisheries Corporation, but more needs to be done.

(iii) Financial sector reform. Commercial banks are reluctant to lend to local businesses despite their ample liquidity. Part of the reason is the inherent risk of start-up lending, the high fixed costs associated with small loans, and the difficulties in collecting on collateral. Moreover, the FSM Development Bank continues to lend to well-established firms rather than supporting start-ups. To improve access to credit, it is necessary to redirect the focus of the FSM Development Bank, expand micro-credit through credit unions and micro-credit agencies, and improve the functioning of the secured transaction framework.

(iv) Reform of the statistical system. Limited domestic capacity to produce economic data prevents understanding of the contribution to the economy of sectors as tourism, fisheries and agriculture, making difficult timely policy response to any shocks to those sectors. Strengthening the statistical capacity is macro-critical, because timely and reliable provision of data is required to assess the economic conditions appropriately and to make necessary policy decisions accordingly.

40. The teams agreed to continue the close cooperation going forward. Appendix I details the specific activities planned by the two country teams over the period September 
2010 - August 2011 along with their expected deliveries. The Bank is currently in the process of reclassifying FSM from an IBRD to an IDA-eligible country. This reclassification will have implications for the Bank's potential lending program and the relevant outcomes of discussions with the government will be shared with the Fund team.

\section{Bank and Fund Planned Activities in Macro-Critical Structural Reform Areas (September 2010-August 2011)}

\begin{tabular}{|c|c|c|c|}
\hline Title & Products & $\begin{array}{l}\text { Provisional Timing } \\
\text { of Missions }\end{array}$ & $\begin{array}{l}\text { Expected Delivery } \\
\text { Date (tentative) }\end{array}$ \\
\hline \multicolumn{4}{|c|}{ A. Mutual information on relevant work programs } \\
\hline $\begin{array}{l}\text { Bank work } \\
\text { program }\end{array}$ & $\begin{array}{l}\text { The potential for Bank's lending } \\
\text { will be discussed with government } \\
\text { after reclassification to IDA status } \\
\text { (currently underway) }\end{array}$ & & \\
\hline $\begin{array}{l}\text { IMF work } \\
\text { program }\end{array}$ & 2010 Article IV Mission & November 2010 & $\begin{array}{l}\text { Board Discussion } \\
\text { expected in January } \\
2011\end{array}$ \\
\hline \multicolumn{4}{|c|}{ B. Request for work program inputs } \\
\hline $\begin{array}{l}\text { Fund request to } \\
\text { Bank }\end{array}$ & $\begin{array}{l}\text { Assessment of macroeconomic } \\
\text { developments and policies } \\
\text { Information sharing }\end{array}$ & $\begin{array}{l}\text { Semi-annual or more } \\
\text { frequent } \\
\text { Semi-annual or more } \\
\text { frequent }\end{array}$ & $\begin{array}{l}\text { Ongoing } \\
\text { Ongoing }\end{array}$ \\
\hline \multirow[t]{2}{*}{$\begin{array}{l}\text { Bank request } \\
\text { to Fund }\end{array}$} & $\begin{array}{l}\text { Assessment of macroeconomic } \\
\text { developments and policies }\end{array}$ & $\begin{array}{l}\text { Semi-annual or more } \\
\text { frequent }\end{array}$ & Ongoing \\
\hline & Information and macro data sharing & $\begin{array}{l}\text { Semi-annual or more } \\
\text { frequent }\end{array}$ & Ongoing \\
\hline \multicolumn{4}{|c|}{ C. Agreement on joint point products and missions } \\
\hline $\begin{array}{l}\text { Joint Work } \\
\text { Program }\end{array}$ & DSA & November 2010 & \\
\hline
\end{tabular}




\section{ANNEX V. MiCRONESIA-STATISTICAL ISSUES \\ As of December 13, 2010, 2010 \\ V. ASSESSMENT OF DATA AdEQUACY FOR SURVEILLANCE}

General: Data have serious shortcomings that significantly hamper surveillance. Shortcomings are most serious in government finance and balance of payments statistics.

National Accounts: External consultants funded by the U.S. Department of Interior have prepared the national income accounts from FY1995 to FY2009. Some shortcomings remain, for instance, no unemployment and investment/savings indicators are available.

Price statistics: A quarterly consumer price index (CPI), rebased to 2008 and utilizing expenditure weights derived from an earlier household survey, is published for the Federated State of Micronesia (FSM) as a whole and each state. However, the data releases suffer from considerable lags, which prevent an accurate and timely evaluation of domestic price movements. For instance, the FY2010 consumer price index has not yet been finalized.

Government finance statistics: The national and the state governments and public sector enterprises publish annual audit reports detailing their fiscal operations; consultants put these data in a GFS format with a lag of about one year. The accuracy of the tax revenue data compiled by the authorities need improvement as they are sometimes different from the audit reports. Further improvements in the quality and timeliness of the fiscal data depend on greater cooperation between the national and state governments. Micronesia does not present fiscal data using the Government Finance Statistics Manual 2001 (GFSM 2001) format.

Monetary statistics: The Banking Commissioner reports monthly monetary data to STA with a two- to three-month lag. The data comprise interest rates, the accounts of the monetary authorities, commercial banks, and the FSM Development Bank. The Commissioner has taken the view that the banking law prevents the sharing of this information outside the Banking Board, hampering domestic surveillance.

Balance of payments: The Office of Statistics, Budget \& Economic Management, Overseas Development Assistance and Compact Management (SBOC) publishes annual estimates of the balance of payments and external debt statistics. The data on workers' remittances are highly incomplete. Delays of data release impart a high degree of uncertainty to analysis of external sector developments. The SBOC aims to produce quarterly balance of payments statistics and to introduce new data sources, such as surveys.

\section{DATA STANDARDS AND QUALITY}

Micronesia does not participate in the IMF's $\quad$ No data ROSC is available.

General Data Dissemination System.

\section{REPORTING TO STA (OPTIONAL)}

Only international liquidity and monetary statistics are currently reported to STA for publication in the International Financial Statistics.

\section{MICRONESIA: TABLE OF COMMON INDICATORS REQUIRED FOR SURVEILLANCE}

AS OF DECEMBER 13, 2010 


\begin{tabular}{|c|c|c|c|c|c|}
\hline & observation & received & Data $^{\prime}$ & Reporting' & publication \\
\hline Exchange Rates & Nov. 2010 & Nov. 2010 & $\mathrm{D}$ & $\mathrm{D}$ & $\mathrm{D}$ \\
\hline $\begin{array}{l}\text { International Reserve Assets and Reserve Liabilities of the } \\
\text { Monetary Authorities } 1\end{array}$ & Aug. 2010 & Nov. 2010 & M & M & M \\
\hline Reserve/Base Money & Aug. 2010 & Nov. 2010 & M & M & NA \\
\hline Broad Money & Aug. 2010 & Nov. 2010 & M & M & NA \\
\hline Central Bank Balance Sheet & Aug. 2010 & Nov. 2010 & M & M & NA \\
\hline Consolidated Balance Sheet of the Banking System & Aug. 2010 & Nov. 2010 & M & M & NA \\
\hline Interest Rates ${ }^{2}$ & Aug. 2010 & Nov. 2010 & M & M & M \\
\hline Consumer Price Index & Aug. 2009 & Nov. 2010 & Q & A & I \\
\hline $\begin{array}{l}\text { Revenue, Expenditure, Balance/Composition of Financing }{ }^{3} \\
\text { General Government }{ }^{4} \text { and Central Government }\end{array}$ & FY2009 & Aug. 2010 & A & A & A \\
\hline $\begin{array}{l}\text { Stocks of Central Government and Central Government- } \\
\text { Guaranteed Debt }\end{array}$ & N/A & N/A & N/A & $\mathrm{N} / \mathrm{A}$ & $\mathrm{N} / \mathrm{A}$ \\
\hline External Current Account Balance & Sep. 2009 & Aug. 2010 & A & A & I \\
\hline Exports and Imports of Goods and Services & Sep. 2009 & Aug. 2010 & A & A & I \\
\hline GDP/GNP & Sep. 2009 & Aug. 2010 & A & A & I \\
\hline Gross External Debt & Sep. 2009 & Aug. 2010 & A & A & 1 \\
\hline International Investment Position ${ }^{6}$ & Sep. 2009 & Aug. 2010 & $A$ & $A$ & $A$ \\
\hline
\end{tabular}

1 Any reserve assets that are pledged of otherwise encumbered should be specified separately. Also, data should comprise short-term liabilities linked to a foreign currency but settled by other means as well as the notional values of financial derivatives to pay and to receive foreign currency, including those linked to a foreign currency but settled by other means.

2 Include the interest rates on consumer loans and commercial loans. Deposit rates are received annually with latest observation for 2009.

3 Foreign, domestic bank, and domestic nonbank financing.

4 The general government consists of the central government (budgetary funds, extra budgetary funds, and social security funds) and state and local governments.

5 Including currency and maturity composition.

6 Includes external gross financial asset and liability positions vis-à-vis nonresidents.

7 Daily (D), Weekly (W), Monthly (M), Quarterly (Q), Annually (A); Irregular (I); Not Available (NA) 


\section{INTERNATIONAL MONETARY FUND}

EXTERNAL

Public Information Notice

RELATIONS

DEPARTMENT

Public Information Notice (PIN) No. 11/19

FOR IMMEDIATE RELEASE

February 4, 2011

International Monetary Fund

$70019^{\text {th }}$ Street, NW

Washington, D. C. 20431 USA

\section{IMF Executive Board Concludes 2010 Article IV Consultation with Micronesia}

On January 26, 2011, the Executive Board of the International Monetary Fund (IMF) concluded the Article IV consultation with the Federated States of Micronesia (FSM). ${ }^{1}$

\section{Background}

The FSM's economy is highly dependent on external aid, and private activity contributes little to growth. A renewed Compact of Free Association agreement ("Compact") with the United States, effective since FY2004, steadily lowers transfers to the FSM through FY2023 and has stricter rules on the use of grants, which have proved difficult for the national and state governments to meet, holding back growth in the FSM economy in recent years.

In addition to delays in Compact grants disbursements, the surge in global commodity prices and the global financial crisis have taken a heavy toll on the FSM economy, with growth remaining in the negative territory for three consecutive years from FY2006 to FY2008. The economy stabilized in FY2009 (0.4 percent growth), mainly supported by infrastructure projects and the rise in subsistence agriculture. Inflation is estimated to have significantly slowed to 3.5 percent in FY2010, after reaching 7.7 percent in FY2009.

The consolidated fiscal balance has also improved, but with differences across states. Some state governments have reduced public employment and salaries in line with the annual decline in Compact grants. Fishing fees temporarily increased along with the rise in fish catch and general tax revenues have expanded thanks to improved tax administration. As a result, the

\footnotetext{
${ }^{1}$ Under Article IV of the IMF's Articles of Agreement, the IMF holds bilateral discussions with members, usually every year. A staff team visits the country, collects economic and financial information, and discusses with officials the country's economic developments and policies. On return to headquarters, the staff prepares a report, which forms the basis for discussion by the Executive Board. At the conclusion of the discussion, the Managing Director, as Chairman of the Board, summarizes the views of Executive Directors, and this summary is transmitted to the country's authorities. An explanation of any qualifiers used in summings up can be found here: http://www.imf.org/external/np/sec/misc/qualifiers.htm.
} 
consolidated overall balance recorded its first surplus in six years of 1.6 percent of GDP in FY2009. However, performance varied across states, with some struggling over a significant amount of debt and others drawing down their savings.

The current account deficit widened and external debt rose in FY2009. High fuel prices and grant-financed imports related to construction activities have worsened the current account. At the same time, external debt rose significantly in FY2009 mainly due to the \$12 million borrowing by the FSM Telecom to finance fiber-optic installation, but the level of debt has remained relatively low at about 30 percent of GDP and is mostly on concessional terms.

The recovery will likely remain weak. Growth in FY2010 is estimated at 0.4 percent, supported mainly by infrastructure projects. The near-term outlook is overshadowed by sluggish private sector growth and the scheduled annual decline in Compact grants. Medium-term growth is estimated to increase slightly to 0.6 percent, supported by additional infrastructure projects in the pipeline. Structural impediments to private sector development and volatile commodity prices could hold back the recovery, and other long-term risks include the possible loss of fish stock and reduction of farmland due to climate change and growing outward migration.

Achieving long-term economic sustainability has become more challenging after the global crisis. Under current projections, lower than anticipated returns on the government's trust fund imply a large projected revenue shortfall in FY2023, when the annual Compact grants are set to expire. Closing this revenue gap would require a substantial fiscal adjustment over the mediumterm.

\section{Executive Board Assessment}

Executive Directors noted that the Micronesian economy had rebounded from the impact of the global crisis and that infrastructure grants in the pipeline are expected to support the modest recovery. Over the medium term, however, further fiscal adjustment and bolder structural reforms will be needed to lift growth prospects, reduce the dependence on grants, and expand the role of the private sector.

Directors welcomed improvements in the fiscal balance. However, they stressed that a credible consolidation strategy, including a timely implementation of tax reform, improvements in tax administration, and tight expenditure control, especially on public sector wages, will be necessary to ensure fiscal sustainability and prepare for the expiry of Compact-related grants. Recognizing the difficulty in implementing these reforms, Directors encouraged the authorities to promote dialogue and coordination at the national level and among the four states. They also emphasized the need to protect critical social and infrastructure spending.

Directors agreed that a multi-year fiscal plan will help guard against spending pressures and guide the authorities' consolidation efforts. They welcomed the steps taken to reduce unfunded liabilities of the social security system. Underscoring the need to reduce the debt, Directors cautioned against using savings to finance current expenditures and against contracting additional foreign loans.

Directors stressed that stepping up structural reforms will accelerate private sector development 
and support fiscal consolidation. They encouraged the authorities to relax FDI legislation, improve labor skills, and strengthen procurement practices to attract foreign investors. Enhancing the capabilities of the statistical office and the quality of economic statistics, particularly for the fiscal accounts, would also strengthen policy planning and evaluation.

Directors welcomed advances in oversight by the Banking Board and observed that granting it operational independence and a well-defined legal authority would further strengthen the supervisory framework. They recommended bringing the FSM Development Bank and other non-deposit taking financial institutions under appropriate regulation and supervision.

Public Information Notices (PINs) form part of the IMF's efforts to promote transparency of the IMF's views and analysis of economic developments and policies. With the consent of the country (or countries) concerned, PINs are issued after Executive Board discussions of Article IV consultations with member countries, of its surveillance of developments at the regional level, of post-program monitoring, and of ex post assessments of member countries with longer-term program engagements. PINs are also issued after Executive Board discussions of general policy matters, unless otherwise decided by the Executive Board in a particular case. The staff report (use the free Adobe Acrobat Reader to view this pdf file) for the 2010 Article IV Consultation with Micronesia is also available. 
Micronesia: Selected Economic Indicators, 2006-10 ${ }^{1 /}$

\begin{tabular}{|c|c|c|c|c|c|}
\hline & FY2006 & FY2007 & FY2008 & FY2009 & $\begin{array}{r}\text { FY2010 } \\
\text { Est. }\end{array}$ \\
\hline \multicolumn{6}{|c|}{ Real sector (average annual percent change unless otherwise noted) } \\
\hline Real GDP & -0.3 & -1.9 & -2.3 & 0.4 & 0.4 \\
\hline Consumer prices & 4.4 & 3.6 & 6.8 & 7.7 & 3.5 \\
\hline Employment & 0.9 & -1.5 & -3.7 & 0.8 & -0.1 \\
\hline Public (incl. public enterprises) & 3.2 & -5.7 & -6.3 & -1.3 & 0.3 \\
\hline Private & -1.9 & 3.5 & -1.0 & 2.9 & -0.5 \\
\hline Nominal wages & 1.8 & 0.6 & 2.9 & 3.4 & 5.8 \\
\hline Public-private wage ratio & 2.2 & 2.2 & 2.2 & 2.3 & 2.3 \\
\hline \multicolumn{6}{|c|}{ Consolidated government finance (in percent of GDP) } \\
\hline Revenue and grants & 55.6 & 56.9 & 57.2 & 66.1 & 60.1 \\
\hline Revenue & 21.8 & 20.7 & 21.2 & 21.4 & 21.3 \\
\hline Grants & 33.7 & 36.2 & 36.0 & 44.7 & 38.8 \\
\hline Expenditure & 60.8 & 59.3 & 58.9 & 64.4 & 59.7 \\
\hline Current & 57.3 & 51.7 & 50.1 & 47.5 & 46.6 \\
\hline Capital & 3.5 & 7.6 & 8.8 & 16.9 & 13.1 \\
\hline Overall balance & -5.2 & -2.4 & -1.7 & 1.6 & 0.4 \\
\hline Compact Trust Fund (millions of U.S. dollars) & 86.5 & 122.6 & 119.1 & 138.3 & 167.9 \\
\hline \multicolumn{6}{|c|}{ Commercial banks (in millions of U.S. dollars; end of period) } \\
\hline Foreign assets & 101.1 & 106.2 & 101.4 & 121.5 & 111.3 \\
\hline Loan & 30.0 & 35.3 & 49.2 & 46.7 & 55.7 \\
\hline Total deposits & 113.7 & 119.5 & 118.9 & 132.5 & 154.1 \\
\hline \multicolumn{6}{|l|}{ Interest rates (in percent, average for $\mathrm{FY}$ ) } \\
\hline Consumer loans & 15.6 & 14.0 & 14.4 & 15.4 & 13.0 \\
\hline Commercial loans & 8.4 & 9.1 & 8.5 & 7.4 & 5.7 \\
\hline \multicolumn{6}{|l|}{ Balance of payments (in millions of U.S. dollars) } \\
\hline Trade balance & -110.8 & -104.4 & -119.4 & -128.0 & -126.5 \\
\hline Net services and income & -24.5 & -18.3 & -25.1 & -31.4 & -20.3 \\
\hline Private and official transfers & 103.1 & 101.1 & 105.1 & 108.0 & 93.9 \\
\hline Current account including official transfers & -32.1 & -21.6 & -39.4 & -51.4 & -53.0 \\
\hline (in percent of GDP) & -12.8 & -8.4 & -15.1 & -18.6 & -18.4 \\
\hline Current account excluding official transfers & -131.7 & -118.0 & -137.9 & -155.5 & -143.1 \\
\hline (in percent of GDP) & -52.4 & -46.1 & -52.7 & -56.2 & -49.8 \\
\hline Overall balance & -1.9 & -0.4 & -5.6 & -5.9 & -1.3 \\
\hline (in percent of GDP) & -0.8 & -0.1 & -2.1 & -2.1 & -0.4 \\
\hline Gross reserves (in months of imports) & 2.9 & 3.1 & 2.5 & 2.7 & 3.0 \\
\hline \multicolumn{6}{|c|}{ External debt (in millions of U.S. dollars; end of period) ${ }^{2 /}$} \\
\hline Stock & 63.4 & 65.9 & 68.0 & 80.5 & 79.2 \\
\hline (in percent of GDP) & 25.2 & 25.8 & 26.0 & 29.1 & 27.6 \\
\hline Debt service & 2.5 & 2.7 & 3.1 & 3.4 & 4.3 \\
\hline (in percent of exports of goods and services) & 5.8 & 5.1 & 5.5 & 6.1 & 7.2 \\
\hline Exchange rate regime & \multicolumn{5}{|c|}{ U.S. dollar is the official currency } \\
\hline Real effective exchange rate ${ }^{3 /}$ & 97.2 & 97.7 & 97.6 & 106.5 & 104.2 \\
\hline
\end{tabular}




\section{Statement by Christopher Legg, Executive Director for the Federates States of Micronesia and Benjamin Pereira, Advisor to the Executive Director \\ January 26, 2011}

\section{Background}

Our Micronesian authorities appreciate staff's frank assessment of the developments in the economy and the constructive exchange of views that characterized these consultations. The consultations provided a timely stock take, prior to the March 2011 elections, of the progress made in recent years, and the remaining challenges to preserve macroeconomic stability and ensure long-term growth.

Micronesia is a small Pacific island country that has a total population of 110, 218 (2006) living on a land area of 700 square kilometers, and scattered across 2.9 million square kilometers of Exclusive Economic Zone (EEZ). The federation consists of four autonomous states guaranteed by its constitution. This autonomy presents complex and diverse challenges for the Federated States of Micronesia.

As noted by staff, Micronesia's recent recovery has been underpinned by the gradual implementation of delayed infrastructure projects. Sustainable growth in the medium to long-term will hinge on improving the implementation of Compact grants, adjusting fiscal policy over the medium-term to the reduction in these grants, and fostering a larger role for the private sector in the economy.

\section{Compact Fund}

The authorities appreciate the continued support from the international community, in particular from the United States through the Compact Fund. However, the mismatch in the capacities that exist in a small island country, like Micronesia, and the administrative requirements of development partners, is a major challenge. To overcome this challenge, our authorities are determined to work with development partners to improve the timely utilization of the Compact Fund and further private sector investments.

\section{Macroeconomic Stability}

\section{Fiscal Policy}

The authorities had made significant progress in restoring medium term fiscal balance, following an average deficit of 5.9 percent of GDP over FY2004-FY2008. This was achieved through the implementation of stringent measures across states, despite social and political risks.

Appendix 1 clearly sets out the size of the fiscal challenge involved to ensure that the current level of public service can be maintained in 2024. With the inability of the Compact Trust Fund (CTF) to supplement expiring Compact-related grants, the authorities acknowledge the necessity of early containment of current expenditures and fiscal reforms in order to attain the required level of fiscal surplus. The authorities also agree with the medium-term target, but the implications of the 
forthcoming election, and the challenge of coordination across states, mean that the path of adjustment will likely be slower.

Nevertheless, my authorities recognize that early containment of current expenditures, in particular public wages, is essential to attaining the required fiscal surplus. For example, notwithstanding the social and political costs, the Chuuk jurisdiction has pursued significant workforce downsizing and reduced working hours for non-Compact related employees, aimed at reducing current expenditures and restoring fiscal balance. But our authorities consider a more targeted approach, rather than across-the-board reductions, to be desirable, given the wide diversity of the fiscal situation confronting the individual states, and the spending pressures associated with the Presidential elections. Such an approach will help ensure priority spending on healthcare, education, and infrastructures are safeguarded. Legislation passed in 2010 has reduced the unfunded liabilities on the social security system and the authorities' continuous monitoring will ensure affordability. The authorities also consider the collection of the consolidated fiscal data a pre-requisite for the development of the multi-year fiscal plan.

\section{Tax Reforms}

The staff report correctly highlights the central importance comprehensive tax reform legislation to create a Unified Revenue Authority (URA) and introduce a net profits tax and value added tax (VAT). Passage of these bills will necessarily have to await the election and the formation of a new government. In the meantime, the authorities will pursue the enhancement of the current operations of the state and national tax offices and broaden personnel training, in anticipation of the broader tax reform. This will be supported by sustained utilization of technical assistance from PFTAC and other development partners, incorporating wherever possible the lessons from the experiences of comparable Pacific island countries that have already undertaken such reforms. Complimenting these efforts, and critical to the success of the reforms, will be a more targeted public awareness program regarding the reforms. In many ways, the Article IV consultation was a watershed moment for officials at all levels of government to understand the value and thinking behind the tax reforms bills. Equally, with the authorities conducting state summits, followed by a national economic summit, economic opportunities and challenges will be fully aired, providing a broader context for issues of tax reform and fiscal sustainability. Technical assistances from the Pacific Forum Secretariat (PFS) and other development partners such as the Secretariat of the Pacific Community (SPC) may be requested, to ensure focused discussions.

\section{External Stability}

Despite the low level of debt to GDP and its concessional nature, the authorities are aware of the fiscal and exchange rate risks posed by foreign denominated loans. Given this, the authorities are committed to closely monitoring the pressures from foreign loans and the scheduled decrements of Compact grants, on external stability.

\section{Financial Sector}

The banking system is highly liquid, with limited lending to the private sector. Nevertheless, the authorities will ensure that the Banking Board is adequately resourced and it's regulatory and supervision capacity is strengthened. The ambit of the Banking Board's powers will be expanded to 
include the development bank and non-deposit taking financial institutions under its regulatory and supervision functions, consistent with international best practice. Continuous use of PFTAC technical assistance will be critical in training new staff and strengthening the Board's capacity for on-sight monitoring of liquidity policies, compliance with AML laws and loan-loss provisions. The newly created Insurance Board will also benefit from technical assistance from the Fund and other agencies, to enhance its supervisory capacity and strengthen foreign corporation auditing.

\section{Private Sector Development}

Although the private sector has been stagnant and has contributed little to growth, it is hoped that the recent completion of key infrastructure projects such as the extension of the Pohnpei airport, the expanded fiber-optic network, and the relocation of a US Marine base to Guam, will support private sector development.

The authorities also see merit in reviewing restrictions imposed by Foreign Investment Acts, at both levels of Government, regarding the ownership and renting of land to harmonize and provide greater clarity on land tenure practices across the states, while respecting local investors' legitimate interests. As always in the Pacific, this is a delicate issue. The lessons learnt from the Pohnpei FDI legislation will assist greatly in refining FDI legislation across FSM. The authorities also recognize the importance of a sustained public consultation strategy on these matters, to ensure broad awareness and acceptance of the need to reform.

The authorities concur with staff that limited availability of skilled labor holds back FDI. They agree that strengthening education and vocational training is critical and note that this is a long term issue that requires more targeted efforts. In this vein, our authorities are working closely with the Asian Development Bank to redesign vocational and education training to ensure effectiveness. Moreover, the authorities believe that the creation of better working conditions, and greater consistency across states, will assist in retaining skilled labor, especially with the forthcoming job opportunities in Guam. These developments will be discussed further at the national summit. In the short run, the authorities believe that relaxing legal restrictions on hiring expatriates may assist, but only if the expatriates' roles are well-defined and targeted, appropriate counterparts are identified and follow-up mechanisms are put in place for knowledge transfer. The authorities will solicit technical assistance to assist in these development efforts.

\section{Adequate Infrastructure}

The strengthening of project management and the capacity to meet procurement requirements for access to external resources remains a medium to long term goal. The authorities will utilize technical assistance from development partners to accelerate the implementation of projects, especially in the context of planned Compact decrements. While utilizing technical assistance, the authorities will ensure that knowledge and skills are transferred to local counterparts, to ensure its sustainability. These efforts will assist greatly with the needed improvements in the power, transportation and communications sectors 


\section{Economic Statistics}

The improvement of the reliability, coverage, and timeliness of economic statistics is critical for policy discussion. The authorities will collect consolidated fiscal data across national and state governments on a timely manner, with technical assistances from PFTAC and SPC. Also, with remittances playing an important role in the Micronesia, the authorities will request the Fund, PFTAC and other development partners for technical assistance.

The authorities continue to value the Fund's assessment of its policies and will welcome a staff visit later this year. 